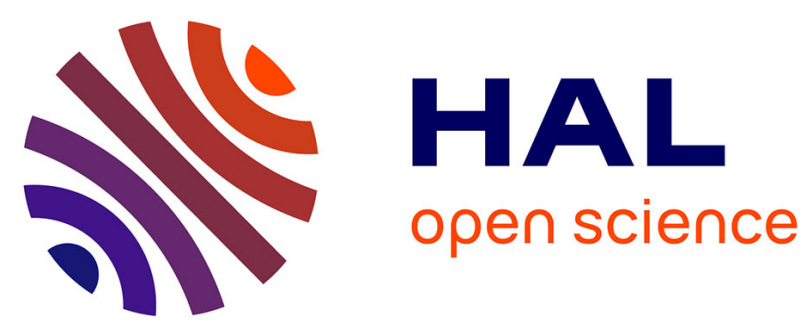

\title{
Exposure to contaminants and nutritional intakes in a French vegetarian population
}

Ségolène Fleury, Gilles Rivière, Benjamin Allès, Emmanuelle Kesse-Guyot, Caroline Méjean, Serge Hercberg, Mathilde Touvier, Nawel Bemrah

\section{To cite this version:}

Ségolène Fleury, Gilles Rivière, Benjamin Allès, Emmanuelle Kesse-Guyot, Caroline Méjean, et al.. Exposure to contaminants and nutritional intakes in a French vegetarian population. Food and Chemical Toxicology, 2017, 109 (1), pp.218-229. 10.1016/j.fct.2017.07.048 . hal-01604582

\section{HAL Id: hal-01604582 \\ https://hal.science/hal-01604582}

Submitted on 26 May 2020

HAL is a multi-disciplinary open access archive for the deposit and dissemination of scientific research documents, whether they are published or not. The documents may come from teaching and research institutions in France or abroad, or from public or private research centers.
L'archive ouverte pluridisciplinaire HAL, est destinée au dépôt et à la diffusion de documents scientifiques de niveau recherche, publiés ou non, émanant des établissements d'enseignement et de recherche français ou étrangers, des laboratoires publics ou privés. 


\section{Accepted Manuscript}

Exposure to contaminants and nutritional intakes in a French vegetarian population

S. Fleury, G. Rivière, B. Allès, E. Kesse-Guyot, C. Méjean, S. Hercberg, M. Touvier, N. Bemrah

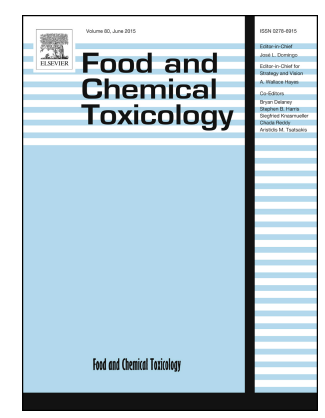

PII: S0278-6915(17)30430-1

DOI: 10.1016/j.fct.2017.07.048

Reference: FCT 9203

To appear in: Food and Chemical Toxicology

Received Date: 19 May 2017

Revised Date: 15 July 2017

Accepted Date: 24 July 2017

Please cite this article as: Fleury, S., Rivière, G., Allès, B., Kesse-Guyot, E., Méjean, C., Hercberg, S., Touvier, M., Bemrah, N., Exposure to contaminants and nutritional intakes in a French vegetarian population, Food and Chemical Toxicology (2017), doi: 10.1016/j.fct.2017.07.048.

This is a PDF file of an unedited manuscript that has been accepted for publication. As a service to our customers we are providing this early version of the manuscript. The manuscript will undergo copyediting, typesetting, and review of the resulting proof before it is published in its final form. Please note that during the production process errors may be discovered which could affect the content, and all legal disclaimers that apply to the journal pertain. 


\section{ACCEPTED MANUSCRIPT}

\section{Exposure to contaminants and nutritional intakes in a French vegetarian population}

S. Fleury ${ }^{1, a}$, G. Rivière ${ }^{1, a}$, B. Allès ${ }^{2}$, E. Kesse-Guyot ${ }^{2}$, C. Méjean ${ }^{2}$, S. Hercberg ${ }^{2}$, M. Touvier $^{2}$ and N. Bemrah $^{1 *}$

${ }^{1}$ Risk Assessment Unit - French Agency for Food, Environmental and Occupational Health \& Safety (ANSES), Maisons-Alfort, France.

${ }^{2}$ Sorbonne Paris Cité Epidemiology and Statistics Research Center (CRESS), Nutritional Epidemiology Research Team (EREN), Inserm U1153, Inra U1125, Conservatoire National des Arts et Métiers (CNAM), Paris 5, 7, 13 Universities,F-93017 Bobigny, France

The conclusions presented in the present article represent authors' views only.

${ }^{a}$ These authors contributed equally to this work.

\section{Abstract}

The NutriNet Santé study collected, on a voluntary basis, the dietary consumption of French vegetarian populations ( $N=1766$, including 188 vegan individuals) from 18 to 81 years (18 to 77 years for the vegan). Taking advantage of the availability of contamination data generated in the context of the second French total diet study, dietary exposures of French vegetarian populations to several contaminants were estimated. Results showed that exposures to persistent organic pollutants (PCBs, PCDD/Fs for instance) was dramatically lower than those of the general French population due to the non consumption of food of animal origins. On the other hand, exposures to phytoestrogens, some mycotoxins (T2 and HT2 toxins) and some trace elements ( $\mathrm{Cd}, \mathrm{Al}, \mathrm{Sn}, \mathrm{Ni})$ were higher in the vegetarian population compared to those of the general population. Despite some limitations of this

\section{* Corresponding author : Nawel Bemrah}

Agence Nationale de Sécurité Sanitaire de l'alimentation, de l'environnement et du travail (Anses)

DER/UERALIM

ACI-COP-4-031

14 rue Pierre et Marie Curie - 94701 Maisons-Alfort Cedex

Tel: +33149773829

Email: nawel.bemrah@anses.fr 


\section{ACCEPTED MANUSCRIPT}

approach (both the consumption study and the total diet study were not aimed to estimate dietary exposure of the vegetarian populations), this study showed that dietary habits can dramatically influence the exposure of some contaminants.

Keywords: chemical exposure, nutritional intake, vegetarian population, health risk assessment.

\section{Introduction}

Since the 70's, the number of studies focusing on vegetarian diet dramatically increased (ScopusAnalyze search results). In early 70's, about 10 scientific publications per year were dealing with vegetarian diet, nowadays every year more than 300 scientific documents deal with this topic. However, it is very difficult to have a clear description of the dietary habits of vegetarian populations since most of the studies published were conducted in small and highly selected samples. Based on the review by Guillocheau (2013), the percentage of vegetarians in the population greatly varies depending on the countries. Whereas it is close to $2 \%$ in France, it reaches $8 \%$ in Germany and as high as $31 \%$ in India.

People choose vegetarianism for several reasons: preservation of natural resources, protection of animal welfare or possible health benefits (Fox et al. 2008). Vegetarianism led to a variety of dietary habits: with or without milk and dairy products, eggs and fish (Leblanc et al. 2000). The American Dietetic Association stated that well-planned vegetarian diets are healthy and nutritionally adequate and might be beneficial in the prevention and treatment of some illnesses. Kahleova et al. (2015) showed that type 2 diabetes is 1.6 to 2 times lower in vegetarians than in the general population. However, vegetarian diet can also be deleterious to human health (Mariotti, 2017). It has been reported that eliminating all animal products from the diet increases the risk of certain nutritional deficiencies. Micronutrients of special concern for vegans include vitamins B-12 and D, calcium, and long-chain n-3 (omega-3) fatty acids Educating the vegetarian population on nutrient supplements is important to reach the recommended daily intakes of each nutrient and prevent pathologies caused by nutritional deficiencies (Mariotti, 2017). In some cases, iron and zinc status of vegans may also be of concern because of the limited bioavailability of these minerals in vegetable sources (Craig W.J. 2009). 


\section{ACCEPTED MANUSCRIPT}

The NutriNet-Santé study (Hercberg et al. 2010) was launched in France in 2009 to investigate the relationships between nutrition and health, the role of various determinants (sociological, economic and cultural) of dietary patterns and nutritional status and also their interactions. The study targeted adult volunteers of 18 years of age or more. On the other hand, a total diet study was run in France (Sirot et al. 2009) that provided information on concentrations of chemicals in food as well as associated dietary exposure for the general population. However, specific subpopulations were not included in this study as well as more sensitive or more exposed populations (Akhandaf et al. 2014).

Taking advantage of the consumption data previously published (Hercberg et al., 2010) and of the contamination data generated in the context of the second total diet study carried out in France, the present study aims to explore the exposure to different chemical contaminants (persistent organic pollutants, trace elements, mycotoxins phytoestrogens, acrylamide and polycyclic aromatic hydrocarbons) and some minerals of the vegetarian population among a French population and was compared to that of the general French population.

\section{Material and methods}

\subsection{Processing consumption data}

The aim of the NutriNet-Sante web-based cohort (Hercberg et al. 2010) is to investigate the relationship between nutrition and health. It also enables to study the role of various determinants (sociological, economic and cultural) of dietary patterns and nutritional status, and their interactions. The study targeted adult volunteers aged 18 years or more.

At inclusion, participants fulfilled a set of five questionnaires related to socio-demographic and lifestyle characteristics (Vergnaud et al., 2011), anthropometrics (Lassale et al., 2013 ; Touvier et al., 2010), dietary intakes (see below), physical activity (validated IPAQ questionnaire) (Craig et al., 2003), and health status.

Dietary intakes were assessed by three non-consecutive validated web-based $24 \mathrm{~h}$-dietary records, randomly assigned over a 2-week period (2 weekdays and 1 weekend day) (Lassale et al., 2016 ; Lassale et al., 2015 ; Touvier et al., 2011). Participants used a dedicated interface of the study website to declare all foods and beverages consumed during a $24 \mathrm{~h}$-period: three main meals (breakfast, lunch, dinner) or any other eating occasion. Portion sizes were estimated using validated photographs 
(LeMoullec et al., 1996). Mean daily energy, alcohol and nutrient intakes were estimated using a published French food composition table (>3 300 items) (Arnault et al., 2013). Amounts consumed from composite dishes were estimated using French recipes validated by food and nutrition professionals. Dietary underreporting was identified on the basis of the method proposed by Black (2000).

Only individuals that self-declared to be vegetarian were considered in the present study. No definition of vegetarianism has been given to the participants. Consequently individuals were categorized based on the food consumption they declared during the NutriNet Santé study.

\subsection{Diet categories}

According to the consumption habits, three categories of diets were defined:

- the pesco-ovo-lacto-vegetarian diet (POLV) included the consumption of fish, seafood, eggs and milk,.

- the ovo-lacto-vegetarian diet (OLV) included the consumption of eggs and milk,

- the vegan diet $(\mathrm{V})$ excluded the consumption or the use of any products from animal origin.

\subsection{Contamination data}

Contamination data generated in the context of the second French total diet study (TDS2) were used in the present study to estimate dietary exposures. A core food approach was chosen: (1) identification of the most commonly consumed foods by the population of interest (90\% of the French total diet) and the main contributors to energy and nutrient intakes; (2) assessment of the mean intake of these foods; (3) sampling of the selected foods, preparation as consumed and analysis; (4) assessment of exposure combining consumption and contamination data (Sirot et al. 2009). The TDS2 selected 445 substances (trace elements and minerals, mycotoxins, contaminants...) of interest that were subsequently measured in 1319 samples of the 212 food items most commonly consumed by the French population (Sirot et al. 2009). Samples were collected between June 2007 and January 2009. Each sample was taken in double to take seasonal variability into account. Foodstuffs were then prepared as consumed, mixed and analyzed by accredited laboratories with validated methods. Each substance was measured in food known or supposed to contain it. 
Contamination values used in the present study were those generated in the context of the second French total diet study. Consequently, some food items of the vegetarian consumption study were not present in the consumption study of the general French population. Unmatched categories had a high consumption rate $(74.9 \%)$ for which the average consumption was $37.1 \mathrm{~g} / \mathrm{d}$ compared to a total consumption around $2600 \mathrm{~g} / \mathrm{d}$. The impact on the calculation was therefore considered as minimal, however a slight underestimation of some exposures could have occurred.

\subsection{Statistical treatment and analyses}

\section{Censored data and hypothesis}

Concentrations below the limit of detection (LOD) or the limit of quantification (LOQ) are referred to as censored data. Lower bound (LB) and upper bound (UB) hypotheses were considered. The LB assumption corresponds to a scenario in which non-detected values are estimated to be 0 and the values detected, but not quantified, are estimated to be equal to the LOD. The UB assumption corresponds to a scenario in which non-detected values are estimated to be equal to the LOD and the values detected but not quantified are estimated to be equal to the LOQ. The LB scenario represents the minimum possible value as it underestimates concentrations below the LOD and those below the LOQ; on the other hand, the UB scenario represents the maximum possible value as it overestimates concentrations below the LOD and those below the LOQ (WHO 1995).

\section{Estimation of the dietary exposure and the nutrient intakes}

Dietary exposures to contaminants or nutrient intakes were calculated with the SAS 9.4. software for every single individual with the following formula:

$$
E_{i}=\sum_{\mathrm{k}=1}^{\mathrm{n}} \frac{\mathrm{C}_{\mathrm{i}, \mathrm{k}} \times \mathrm{L}_{\mathrm{k}}}{\mathrm{BW}_{\mathrm{i}}}
$$


Where $E_{i}$ is the exposure (or nutrient intake) of individual $\mathrm{i}, n$ the number of foodstuff that has been consumed by individual $\mathrm{i}, \mathrm{C}_{\mathrm{i}, \mathrm{k}}$ the amount consumed of the food $\mathrm{k}$ (in $\mathrm{g} /$ day) by the individual $\mathrm{i}, \mathrm{L}_{\mathrm{k}}$ the level of contamination (or nutrient content) in the food $\mathrm{k}, \mathrm{BW}_{\mathrm{i}}$ the individual body weight (in $\mathrm{kg}$ ) of the individual i.

\subsection{Risk characterization}

The estimated exposures were compared to reference values in order to characterize the risk. Tolerable daily intake (TDI), provisional tolerable weekly intake (PTWI) or provisional Tolerable Monthly Intake (PTMI) were considered for substances with a threshold effect. Benchmark dose limits (BMDL) were also considered (including for some compounds known to show genotoxic activity - non threshold compounds). The $\left(\mathrm{BMDL}_{01}\right),(\mathrm{BMDL})$ or $\left(\mathrm{BMDL}_{10}\right)$ are equivalent to an increasing of respectively $1 \%, 5 \%$ or $10 \%$ of the effects selected to set the health based guidance value. These health-based guidance values (HBGV) have been established by scientific instances (French, European or International). In the present study, only dietary exposures were considered. Additional routes of exposure (dermal, inhalation) were not considered. The methodology of total diet studies does not allow either to evaluate intakes and exposure in particular situations like in the case of an accidental or local contamination of food. It does not enable to characterize the risk relying to the consumption of "organic food" or imported products (Sirot et al. 2009).

\section{Results and discussion}

\subsection{Population characteristics and consumption habits}

In June 2014, 1766 individuals were registered as vegetarians in the NutriNet-Santé study. The majority of individuals were women (83\%). Most of the volunteers were between 18 and 54 years of age for females and between 18 and 64 years of age for males ( $90 \%$ of the entire population). The mean age was $36.6 \pm 12.9$ (SD) years. The body mass index (BMI) ranged between 13.3 and 45.3 kg.m². A majority of individuals had a BMI ranging from 18.5 to 25 (Figure 1). $69.0 \%$ of the population 


\section{ACCEPTED MANUSCRIPT}

had higher education with more than a half graduated a $2^{\text {nd }}$ or a $3^{\text {rd }}$ cycle. Socio-professional categories that were most represented in the studied population were intellectual functions $(21.3 \%)$ and employees (18.9\%). The most represented vegetarian diet was the OLV diet $(54.9 \%$ of the population). The POLV diet was the second most represented diet (34.4\%) and the vegan was the less represented (10.7\%) (Figure 2).

Twelve individuals did not indicate their bodyweight in the database and were excluded from the database and 1754 individuals were finally included in the analysis.

\subsection{Consumption}

Consumption rate by food groups ranged from 0 (meat, poultry and game, offal and delicatessen meats) to $98.4 \%$ (for vegetables). Food groups that had the highest consumption rates were: vegetables (excluding potatoes) (98.4\%), drinking water (96.2\%), condiments and sauces (95.3\%), bread and dry bakery (93.5\%) and fruits (92.8\%). In the general French population (Dubuisson et al., 2010), similar consumption rates were observed in the following food groups: vegetables, meat or cheese. Mean consumption quantities ranged from 0 to $649 \mathrm{~g} / \mathrm{d}$. Highest quantities consumed were water $\left(649 \mathrm{~g} \mathrm{~d}^{-1}\right)$, hot beverages $\left(346.9 \mathrm{~g} \mathrm{~d}^{-1}\right)$, vegetables (excluding potatoes) $\left(240 \mathrm{~g} \mathrm{~d}^{-1}\right)$ and fruits (225 g/d). In the general French population, food groups that had the highest consumption mean values were similar to those in the present study. The consumption of vegetables and hot beverages in the vegetarian population was higher than that in the general French population (240 versus $139.3 \mathrm{~g}$ $\mathrm{d}^{-1}$ and 346.9 versus $129.5 \mathrm{~g} \mathrm{~d}^{-1}$, respectively) whereas the consumption of alcoholic drinks was more consumed in the general population than that in the vegetarian population (154.8 versus $62.6 \mathrm{~g} \mathrm{~d}^{-1}$, respectively) (Table 2).

Highest mean consumption quantities of slow-release carbohydrates were from bread and dried bread products. The mean consumption of these products $\left(82.7 \mathrm{~g} \mathrm{~d}^{-1}\right)$ was lower than that reported for the general French population $\left(115 \mathrm{~g} \mathrm{~d}^{-1}\right)$. This was also the case for potatoes. However, the percentages of consumers of cooked fruits and compotes, breakfast cereals, other cereals and chocolate were higher than those in the general French population. These food items were also more consumed by 


\section{ACCEPTED MANUSCRIPT}

the vegetarian population compared to the general French population (Table 2). Seafood and eggs were less consumed by vegetarians than by the general French population (about 1.5-2 times). Nevertheless, vegetables and fruits were consumed in higher quantities and by a larger part of the vegetarian population in comparison to the general French population.

\subsection{Dietary exposure and risk characterization}

\section{Trace elements and minerals}

$\operatorname{Arsenic~(As)~}$

The mean exposure to total As in the vegetarian population ranged from $0.56 \mu \mathrm{g} \cdot \mathrm{kg} \mathrm{bw}^{-1} \cdot \mathrm{d}^{-1}$ (LB) to $0.64 \mu \mathrm{g} \cdot \mathrm{kg} \mathrm{bw}^{-1} \cdot \mathrm{d}^{-1}$ (UB). At the $95^{\text {th }}$ percentile, the exposure was $2.08 \mu \mathrm{g} \cdot \mathrm{kg} \mathrm{bw}^{-1} \cdot \mathrm{d}^{-1}$ (LB) and 2.17 $\mu \mathrm{g} \cdot \mathrm{kg} \mathrm{bw}^{-1} \cdot \mathrm{d}^{-1}$ (UB). Main arsenic contributors were fish (LB: $23.7 \%$, UB: $20.8 \%$ ), crustaceans and mollusks (LB: $13.1 \%$, UB: $11.5 \%$ ) and mixed dishes (LB: $11.8 \%$, UB: $10.5 \%$ ). These results showed that the mean exposure of the vegetarian population was lower than that of the general French population (MB: $0.8 \mu \mathrm{g} \cdot \mathrm{kg} \mathrm{bw}^{-1} \cdot \mathrm{d}^{-1}$, Arnich et al., 2010). However, the $95^{\text {th }}$ percentile was higher for vegetarian population than that of the general population (MB: $\left.1.79 \mu \mathrm{g} \cdot \mathrm{kg} \mathrm{bw}^{-1} \cdot \mathrm{d}^{-1}\right) .95^{\text {th }}$ percentiles for the LB and the UB hypotheses were in the range of the two benchmark dose lower limit values the JECFA established for inorganic arsenic $\left(\mathrm{BMDL}_{01}\right.$ set between 0.3 and $\left.8 \mu \mathrm{g} \cdot \mathrm{kg} \mathrm{bw}^{-1} \cdot \mathrm{d}^{-1}\right)$ based on cancer effect. The margins of exposure (MOEs) were lower than that calculated in the context of the second total diet study performed in France (Arnich et al., 2010). Arsenic was already of health concern for the general population in France and consequently also is for the vegetarian population. These exposures were higher than those previously reported by Clarke et al. (2003) for a vegetarian population in the United-Kingdom (mean dietary exposure: $0.018 \mathrm{mg}^{-\mathrm{d}^{-1}}$ resulting in $0.3 \mu \mathrm{g} \cdot \mathrm{kg} \mathrm{bw}^{-1} . \mathrm{d}^{-1}$ considering a $60 \mathrm{~kg}$ bw adult).

$\operatorname{Lead}(\mathrm{Pb})$ 
Mean exposure of the vegetarian population to lead was estimated at $0.18 \mu \mathrm{g} \cdot \mathrm{kg} \mathrm{bw}^{-1} \cdot \mathrm{d}^{-1}$ for the LB hypothesis and $0.23 \mu \mathrm{g} \cdot \mathrm{kg} \mathrm{bw}^{-1} \cdot \mathrm{d}^{-1}$ for the UB hypothesis. At the $95^{\text {th }}$ percentile, exposure was 0.33 $\mu \mathrm{g} \cdot \mathrm{kg} \mathrm{bw}^{-1} \cdot \mathrm{d}^{-1}$ (LB) and $0.40 \mu \mathrm{g} \cdot \mathrm{kg} \mathrm{bw}^{-1} \cdot \mathrm{d}^{-1}$ (UB). Main lead contributors were vegetables (excluding potatoes) (LB: $18.0 \%$, UB: $17.4 \%$ ), bread and dry baking products (LB: $14.3 \%$, UB: $13.8 \%$ ). These exposure values were quite similar to those observed in the general French population (mean: 0.2 $\mu \mathrm{g} \cdot \mathrm{kg} \mathrm{bw}^{-1} \cdot \mathrm{d}^{-1}$ and $95^{\text {th }}$ percentile: $\left.0.35 \mu \mathrm{g} \cdot \mathrm{kg} \mathrm{bw}^{-1} \cdot \mathrm{d}^{-1}\right)$. In the general French population, the main contributors were alcoholic beverages (14\%) and bread and dried bread products (13\%). Considering the BMDL $L_{01}$ established by EFSA $\left(0.63 \mu \mathrm{g} \cdot \mathrm{kg} \mathrm{bw}^{-1} . \mathrm{d}^{-1}\right.$ for nephrotoxic effects and $1.5 \mu \mathrm{g} \cdot \mathrm{kg} \mathrm{bw}^{-1} \cdot \mathrm{d}^{-1}$ for cardiovascular effects) (EFSA, 2012), the MOEs were between 2.2 and 8.3 for the mean and between 1.3 and 4.5 for the $95^{\text {th }}$ percentile. Consequently, the risk cannot be excluded for lead for the vegetarian population. Exposures calculated in the present article were lower than those estimated for a population of vegetarian in the United Kingdom $\left(0.016 \mathrm{mg}^{-1} \mathrm{~d}^{-1}\right.$ resulting in $0.26 \mu \mathrm{g} \cdot \mathrm{kg} \mathrm{bw}^{-1} \cdot \mathrm{d}^{-1}$ for a 60 kg bw adult; Clarke et al., 2003).

\section{Cadmium (Cd)}

The mean cadmium exposure for the vegetarian population was $1.12 \mu \mathrm{g} \cdot \mathrm{kg} \mathrm{bw}^{-1} \cdot \mathrm{week}^{-1}$ for the LB hypothesis and $1.19 \mu \mathrm{g} . \mathrm{kg} \mathrm{bw}^{-1}$. week ${ }^{-1}$ for the UB hypothesis. At the $95^{\text {th }}$ percentile, exposure was $1.96 \mu \mathrm{g} \cdot \mathrm{kg} \mathrm{bw}^{-1} \cdot$ week $^{-1}$ (LB) and $2.03 \mu \mathrm{g} \cdot \mathrm{kg} \mathrm{bw}^{-1} \cdot$ week $^{-1}$ (UB). Main contributors were vegetables (excluding potatoes) (LB: 18.0\%, UB: 17.4\%), and bread and dried bread products (LB: $14.3 \%$, UB: $13.8 \%)$. These exposure values were very close to those reported for the general French population. However, the highest contributor was potatoes compared to vegetables in the present study. Exposure at the $95^{\text {th }}$ percentile for the vegetarian population was below the tolerable weekly intake established at $2.5 \mu \mathrm{g} \cdot \mathrm{kg} \mathrm{bw}^{-1}$. week ${ }^{-1}$ based on the nephrotoxic effects of cadmium (EFSA 2009). Some exceedances of this value were still observed for $1.25 \%$ of the population for LB hypothesis and $1.47 \%$ of the population for the UB hypothesis. French estimates for the vegetarian population were close to that estimated for the vegetarian in the United-Kingdom $\left(1.75 \mu \mathrm{g} \cdot \mathrm{kg} \mathrm{bw}^{-1} \cdot \mathrm{week}^{-1}\right.$ for a $60 \mathrm{~kg}$ bw adult) estimated in the Clarke et al study (2003). 
Aluminum (Al)

The mean aluminum exposure for the vegetarian population was estimated at $0.39 \mathrm{mg} \cdot \mathrm{kg} \mathrm{bw}^{-1} \cdot$ week $^{-1}$ for the LB hypothesis and $0.40 \mathrm{mg} \cdot \mathrm{kg} \mathrm{bw}^{-1} \cdot \mathrm{week}^{-1}$ for the UB hypothesis. At the $95^{\text {th }}$ percentile, exposure was $0.74 \mathrm{mg} \cdot \mathrm{kg} \mathrm{bw}^{-1} \cdot$ week $^{-1}$ (LB) and $0.76 \mathrm{mg} \cdot \mathrm{kg} \mathrm{bw}^{-1} \cdot \mathrm{week}^{-1}$ (UB). Main aluminum contributors were hot beverages (LB: $25.7 \%$, UB: $24.7 \%$ ) and vegetables (excluding potatoes) (LB: $12.9 \%$, UB: $12.9 \%$ ). Exposure to aluminum of the vegetarian population was 1.5 times higher than that observed for the general French population. However, the exposure at the $95^{\text {th }}$ percentile in the present study was below the provisional weekly tolerable intake value offset at $1 \mathrm{mg} \cdot \mathrm{kg} \mathrm{bw}^{-1} \cdot \mathrm{week}^{-1}$ (EFSA, 2008a). Clarke et al (2003) calculated dietary exposures of aluminum in the same order of magnitude than those reported here.

\section{$\operatorname{Mercury}(\mathrm{Hg})$}

The mean exposure of the vegetarian population from the present study to mercury was estimated at $0.02 \mu \mathrm{g} \cdot \mathrm{kg} \mathrm{bw}^{-1} \cdot$ week $^{-1}$ for the LB hypothesis and $0.16 \mu \mathrm{g} \cdot \mathrm{kg} \mathrm{bw}^{-1} \cdot$ week $^{-1}$ for the UB hypothesis. At the $95^{\text {th }}$ percentile, exposure was $0.07 \mu \mathrm{g} \cdot \mathrm{kg} \mathrm{bw}^{-1} \cdot$ week $^{-1}$ (LB) and $0.28 \mu \mathrm{g} \cdot \mathrm{kg} \mathrm{bw}^{-1} \cdot \mathrm{week}^{-1}$ (UB). Main mercury contributors were fish (LB: $33.5 \%$, UB: $20.1 \%$ ), chocolate for the LB hypothesis (LB: $23.2 \%$, UB: $2.7 \%$ ) and fruits for the UB hypothesis (LB: $0.5 \%$, UB: $11.0 \%$ ). Only total mercury concentration data were available, and no hypothesis for speciation was considered to characterize the risk due to inorganic and organic mercury. However, the exposure of total mercury in the vegetarian population was in the same order of magnitude than those of the general population showing that dietary exposure to mercury is of concern for general population. Consequently, the risk due to mercury in food cannot be excluded for the vegetarian population. Mean exposure calculated for a vegetarian population in the United-Kingdom $\left(0.15 \mu \mathrm{g} . \mathrm{kg} \mathrm{bw}^{-1} . \mathrm{d}^{-1}\right.$ for a $60 \mathrm{~kg}$ bw adult; Clarke et al., 2003) was close to the exposure estimated in the present article. 
$\operatorname{Tin}(S n)$

Mean exposure to tin of the vegetarian population was estimated at $6.30 \mu \mathrm{g} \cdot \mathrm{kg} \mathrm{bw}^{-1} \cdot \mathrm{d}^{-1}$ for the LB hypothesis and $6.32 \mu \mathrm{g} \cdot \mathrm{kg} \mathrm{bw}^{-1} \cdot \mathrm{d}^{-1}$ for the UB hypothesis. At the $95^{\text {th }}$ percentile, exposure was 31.1 $\mu \mathrm{g} . \mathrm{kg} \mathrm{bw}^{-1} \cdot \mathrm{d}^{-1}$ for both hypotheses. Main tin contributors were fruits (LB: $58.8 \%$, UB: $58.7 \%$ ) and cooked fruits and compotes (LB: $15.8 \%$, UB: $15.8 \%$ ). Exposure to tin in the present study was twice that observed for the general French population. Health based guidance value has been established for organic or inorganic tin whereas only total tin concentrations were available for the calculation of the vegetarian population; consequently, no comparison with toxicological values could be made. The estimated dietary exposure to tin in a vegetarian population in the United-Kingdom was $65 \mu \mathrm{g} . \mathrm{kg} \mathrm{bw}$ ${ }^{1} \cdot d^{-1}$ (Clarke et al., 2003).

\section{Nickel (Ni)}

Mean exposure of vegetarians from the present study was estimated at $2.95 \mu \mathrm{g} \cdot \mathrm{kg} \mathrm{bw}^{-1} \cdot \mathrm{d}^{-1}$ for the LB hypothesis and $3.36 \mu \mathrm{g} . \mathrm{kg} \mathrm{bw}^{-1} . \mathrm{d}^{-1}$ for the UB hypothesis. At the $95^{\text {th }}$ percentile, exposure was 5.45 $\mu \mathrm{g} \cdot \mathrm{kg} \mathrm{bw}^{-1} \cdot \mathrm{d}^{-1}$ (LB) and $6.16 \mu \mathrm{g} \cdot \mathrm{kg} \mathrm{bw}^{-1} \cdot \mathrm{d}^{-1}$ (UB). Main nickel contributors were dried fruits, nuts and seeds (LB: 14.4\%, UB: 12.7\%) and fruits (LB: 10.3\%, UB: 10.2\%). Nickel exposures were between 1.2 and 1.6 times higher than those for the general French population. $60 \%$ of the population had nickel exposure exceeding the health based guidance value established by EFSA (Efsa, 2015) at $2.8 \mu \mathrm{g} . \mathrm{kg}$ $b w^{-1} \cdot d^{-1}$. Consequently, with regard to nickel he risk cannot be excluded for the vegetarian population. The results from Clarke et al (2003) in a vegetarian population in the United-Kingdom were in the same range as those of the presently reported values for the French population $\left(3 \mu \mathrm{g} \cdot \mathrm{kg} \mathrm{bw}^{-1} \cdot \mathrm{d}^{-1}\right.$ for a $60 \mathrm{~kg}$ bw adult).

\section{Calcium (Ca)}

Mean Ca intake of the vegetarian was estimated at $580 \mathrm{mg} \cdot \mathrm{d}^{-1}$. At the $95^{\text {th }}$ percentile, intake was 1055 $\mathrm{mg} \cdot \mathrm{d}^{-1}$. Main contributors to $\mathrm{Ca}$ intake were cheese $(14.6 \%)$ and hot beverages $(14.1 \%)$. These 
intakes were $25 \%$ lower than those observed in the general population and were below the recommended values $\left(900 \mathrm{mg}^{-\mathrm{d}^{-1}}\right.$ for adults and $1200 \mathrm{mg}^{-\mathrm{d}^{-1}}$ for women older than 55 and men older than 65, Guéguen 2001).

\section{Magnesium (Mg)}

Mean Mg intake of the vegetarian population was estimated at $284 \mathrm{mg} \cdot \mathrm{d}^{-1}$ and $453 \mathrm{mg} \cdot \mathrm{d}^{-1}$ at the $95^{\text {th }}$ percentile. Main magnesium contributors were bread and dry baking products (LB \& UB: $10.6 \%$ ) and dried fruits, nuts and seeds (LB \& UB: 10.0\%). Intakes values from the NutriNet-Santé study and the previously reported values for the general French population are similar (Kalonji et al. 2015). Mean intake was slightly lower than the recommended dietary allowance (between 360 and $420 \mathrm{mg}^{-1} \mathrm{~d}^{-1}$ ) but $95^{\text {th }}$ percentile value was below the security limit.

\section{Copper (Cu)}

Mean Cu intake of the vegetarian population was estimated at $1.59 \mathrm{mg} \cdot \mathrm{d}^{-1}$. Intake at the $95^{\text {th }}$ percentile was $3.0 \mathrm{mg} \cdot \mathrm{d}^{-1}$. Main copper contributors were coffee $(19.8 \%)$ dried fruits and oil seeds $(10.0 \%)$. These intakes were $20 \%$ to $25 \%$ lower than those for the general population (Kalonji et al., 2015). Recommended dietary intakes being 1.5 and $2 \mathrm{mg} \cdot \mathrm{d}^{-1}$ (Coudray 2001) these were adequate and below the security limit $\left(5 \mathrm{mg} \cdot \mathrm{d}^{-1}\right)$. The vegetarian population in the United-Kingdom had a mean copper intake of $1.4 \mathrm{mg} \cdot \mathrm{d}^{-1}$ according to Clarke et al. (2003).

\section{Sodium (Na)}

Mean $\mathrm{Na}$ intake of the vegetarian population was estimated at $1.7 \mathrm{~g} \cdot \mathrm{d}^{-1}$. At the $95^{\text {th }}$ percentile, intake was 2.9 g. $\mathrm{d}^{-1}$. Main sodium contributors were bread and dry baking (28.5\%) and condiments and sauces $(10.0 \%)$. Intakes in the present study were $40 \%$ lower than that for the general population and lower than recommendations (2.36 g.d $\mathrm{d}^{-1}$ and $3.14 \mathrm{~g} . \mathrm{d}^{-1}$ ) (Kalonji et al. 2015). This difference might be due to the fact that vegetarian consume no processed meat which is one of the main contributors to the exposure of $\mathrm{Na}$ in the general population. 
Iron $(F e)$

Mean Fe intake of the vegetarian population was estimated at $7.1 \mathrm{mg} \cdot \mathrm{d}^{-1}$. At the $95^{\text {th }}$ percentile, intake was $13.1 \mathrm{mg} \cdot \mathrm{d}^{-1}$. These intakes were close to those already reported for the general population (Kalonji et al. 2015).

Main iron contributors in the vegetarian population were coffee (19.8\%) and dried fruits and oil seeds $(10.0 \%)$

Summary for trace elements and minerals

Considering the vegetarian population, the risk cannot be excluded for several TEM; this is the case for $\mathrm{Cd}, \mathrm{Al}, \mathrm{Ni}, \mathrm{Mg}, \mathrm{Cu}, \mathrm{Na}$ and $\mathrm{Fe}$. Studied vegetarian population was more exposed to cadmium and aluminum than the general French population. On the other hand, lower intakes have been calculated for the vegetarian population than those for the general French population for $\mathrm{Mg}, \mathrm{Cu}, \mathrm{Na}$ and $\mathrm{Fe} . \mathrm{Mg}$ and Fe intakes were below RDA values but copper and sodium intakes were close to those values. In the present study, percentage of individuals exceeding the respective recommended values for $\mathrm{Cd}, \mathrm{Al}$, $\mathrm{Ni}$ and $\mathrm{Mg}$ were higher than those of the general population (between 2.5 and 10 times higher). For As and Fe, the risk could not be excluded for both contaminants. The risk could be ruled out for the studied vegetarian population for $\mathrm{Ca}$. However, Ca intakes were below RDA values.

Compared to the general population, it appeared that some exceedances of the health based guidance values were for the same substances except for $\mathrm{Ca}$ for which intakes were lower in vegetarian populations (no exceeding) and $\mathrm{Ni}$ for which the health based guidance value was dramatically decreased between the second total diet study published in 2009 and the present study.

\section{Persistent organic pollutants}




\section{ACCEPTED MANUSCRIPT}

Dioxins (PCDDs), furans (PCDFs), polychlorobiphenyls (PCBs)

As one of the main contributor to dioxins, furans and PCB exposure are fish, exposures of the vegan and non-vegan have been calculated separately. PCDD/F + dioxin-like PCBs (dl-PCBs) exposures were calculated using the toxicological equivalent factors (regulation (UE) $n^{\circ} 1259 / 2011$ ) known as $\mathrm{TEF}_{\mathrm{WHO} 2005}$. The selected health based guidance value was the monthly tolerable intake set by JECFA (2001), $70 \mathrm{pg} T E Q_{\text {wно }} \cdot \mathrm{kg} \mathrm{bw}^{-1} \cdot \mathrm{month}^{-1}$, ie, $2.33 \mathrm{pg} T E Q_{\text {wно }} \cdot \mathrm{kg} \mathrm{bw}^{-1} \cdot \mathrm{d}^{-1}$. With regard to non dioxin like PCBs (ndl-PCBs), the health based guidance value set by Afssa at $10 \mathrm{ng} \cdot \mathrm{kg} \mathrm{bw}^{-1} \cdot \mathrm{d}^{-1}$ was selected (Sirot et al. 2012a).

\section{Exposures of all vegetarian populations (including vegan)}

For the NutriNet Santé study, vegetarian population, the mean exposure to PCDD/Fs + dl-PCBs was

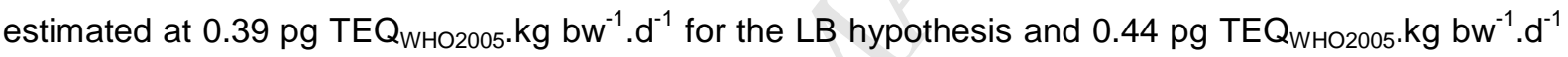
for the UB hypothesis. At the $95^{\text {th }}$ percentile, exposure was $1.46 \mathrm{pg} \mathrm{TEQ} \mathrm{WHO2005} \cdot \mathrm{kg} \mathrm{bw}^{-1} \cdot \mathrm{d}^{-1}$ (LB) and $1.56 \mathrm{pg}$ TEQ ${ }_{w \text { Hо2005. }} \mathrm{kg} \mathrm{bw}^{-1} \cdot \mathrm{d}^{-1}$ (UB). Main PCDD/Fs + dl-PCBs contributors were fish (LB: $23.5 \%$, UB: $21.9 \%$ ) and cheese (LB: $17.2 \%$, UB: 16.1\%). In the case of ndl-PCBs, vegetarians had a mean exposure of $0.97 \mathrm{ng} \cdot \mathrm{kg} \mathrm{bw}^{-1} \cdot \mathrm{d}^{-1}$. At the $95^{\text {th }}$ percentile, exposure was $4.64 \mathrm{ng} \cdot \mathrm{kg} \mathrm{bw}^{-1} \cdot \mathrm{d}^{-1}$. Main ndlPCBs contributors were fish (47.3\%) and mixed dishes (11.7\%). Vegetarian exposures to ndl-PCBs and PCDD/Fs + dl-PCBs were all below their respective health based guidance value.

\section{Exposures of the vegan population}

Mean vegan exposure to PCDD/Fs + dl-PCBs was estimated at $0.053 \mathrm{pg} T \mathrm{TEQ}_{\mathrm{wHO}} \mathrm{2005} \cdot \mathrm{kg} \mathrm{bw}^{-1} \cdot \mathrm{d}^{-1}$ (LB) and $0.073 \mathrm{pg} \mathrm{TEQ} \mathrm{WHO2005}_{\mathrm{kg}} \mathrm{bw}^{-1} \cdot \mathrm{d}^{-1}(\mathrm{UB})$. Exposure at the $95^{\text {th }}$ percentile was $0.190 \mathrm{pg}$ TEQ ${ }_{W H O 2005} \cdot \mathrm{kg} \mathrm{bw}^{-1} \cdot \mathrm{d}^{-1}$ (LB) and $0.230 \mathrm{pg}$ TEQwHO2005. $\mathrm{kg} \mathrm{bw}^{-1} \cdot \mathrm{d}^{-1}$ (UB). Main PCDD/Fs + dl-PCBs contributors were oil (LB: $48.6 \%$, UB: $54.4 \%$ ) and pizzas, quiches, savoury pastries and cakes (LB: $22.3 \%$, UB: $16.4 \%)$. 


\section{ACCEPTED MANUSCRIPT}

Mean exposure to ndl-PCBs was estimated at $0.068 \mathrm{ng} \cdot \mathrm{kg} \mathrm{bw}^{-1} \cdot \mathrm{d}^{-1}$ for both hypotheses. At the $95^{\text {th }}$ percentile, exposure was $0.284 \mathrm{ng} \cdot \mathrm{kg} \mathrm{bw}^{-1} \cdot \mathrm{d}^{-1}$. Main ndl-PCBs contributors were oil (42.6\%) and pizzas, quiches, savoury pastries and cakes (27.7\%). Vegan mean exposure to PCDD/Fs + dl-PCBs was 15 to 30 times lower than that of the general population.

\section{Exposures of the non-vegan population}

Non-vegan population had a mean exposure to PCDD/Fs + dl-PCBs of $0.429 \mathrm{pg} T \mathrm{TEQ}_{\mathrm{wHO}}{ }^{2005} \cdot \mathrm{kg} \mathrm{bw}^{-1} \cdot \mathrm{d}^{-}$

${ }^{1}$ for the LB hypothesis and $0.480 \mathrm{pg} \mathrm{TEQ}{ }_{W H O 2005} \cdot \mathrm{kg} \mathrm{bw}^{-1} \cdot \mathrm{d}^{-1}$ for the UB hypothesis. At the $95^{\text {th }}$ percentile, exposure was $1.57 \mathrm{pg} \mathrm{TEQ}_{W H O 2005} \cdot \mathrm{kg} \mathrm{bw}^{-1} \cdot \mathrm{d}^{-1}$ (LB) and $1.61 \mathrm{pg} \mathrm{TEQ}_{\mathrm{WHO2005}} \cdot \mathrm{kg} \mathrm{bw}^{-1} \cdot \mathrm{d}^{-1}$ (UB). Main PCDD/F + dl-PCBs contributors were fish (LB: $23.1 \%$, UB: $21.6 \%$ ) and cheese (LB: $18.0 \%$, UB: $16.7 \%)$.

The mean exposure to ndl-PCBs was estimated at $1.08 \mathrm{ng} \cdot \mathrm{kg} \mathrm{bw}^{-1} \cdot \mathrm{d}^{-1}$ for both the lower and upper bound hypotheses. At the $95^{\text {th }}$ percentile, exposure was $5.45 \mathrm{ng} \cdot \mathrm{kg} \mathrm{bw}^{-1} \cdot \mathrm{d}^{-1}$ for both hypotheses. Main ndl-PCBs contributors were fish (47.8\%) and mixed dishes (11.7\%).

\section{Perfluoalkyl acids}

Mean vegetarians exposures to Perfluorooctanesulfonic acid (PFOS) was estimated at $0.031 \mathrm{ng} . \mathrm{kg}$ $b w^{-1} \cdot d^{-1}$ for LB hypothesis and $0.447 \mathrm{ng} \cdot \mathrm{kg} \mathrm{bw}^{-1} \cdot \mathrm{d}^{-1}$ for UB hypothesis. Perfluorooctanoic acid (PFOA) mean exposure was about $0.005 \mathrm{ng} \cdot \mathrm{kg} \mathrm{bw}^{-1} \cdot \mathrm{d}^{-1}$ for LB hypothesis and $0.429 \mathrm{ng} \cdot \mathrm{kg} \mathrm{bw}^{-1} \cdot \mathrm{d}^{-1}$ for UB hypothesis. At the $95^{\text {th }}$ percentile, exposure was $0.177 \mathrm{ng} \cdot \mathrm{kg} \mathrm{bw}^{-1} \cdot \mathrm{d}^{-1}$ (LB) and $1.020 \mathrm{ng} \cdot \mathrm{kg} \mathrm{bw}^{-1} \cdot \mathrm{d}^{-1}$ (UB) for PFOS and $0.016 \mathrm{ng} \cdot \mathrm{kg} \mathrm{bw}^{-1} \cdot \mathrm{d}^{-1}$ (LB) and $0.0963 \mathrm{ng} \cdot \mathrm{kg} \mathrm{bw}^{-1} \cdot \mathrm{d}^{-1}$ (UB) for PFOA. Main contributors to PFOS and PFOA were fish (LB: $35.4 \%$, UB: $34.6 \%$ ) and cheese (LB: $14.2 \%$, UB: 13.6\%). Except for the exposure of PFOS at the $95^{\text {th }}$ percentile, vegetarian exposure to perfluoalkyl acids was lower than that described for the general French population (Rivière et al. 2014). Values at the $95^{\text {th }}$ percentile were far below health based guidance values (PFOS: $0.15 \mu \mathrm{g} \cdot \mathrm{kg} \mathrm{bw}^{-1} \cdot \mathrm{d}^{-1}$ and PFOA: $1.5 \mu \mathrm{g} \cdot \mathrm{kg} \mathrm{bw}^{-1} \cdot \mathrm{d}^{-1}$, EFSA, 2008b). 
Health based guidance value for PBB was established by EFSA at $0.15 \mathrm{mg} \cdot \mathrm{kg} \mathrm{bw}^{-1} \cdot \mathrm{d}^{-1}$ (EFSA 2010a). PBDE have a chemical structure and a mechanism of action very similar to ndl-PCBs (Rivière et al. 2014). Consequently, the health based guidance value established for ndl-PCBs (10 ng.kg bw ${ }^{-1} \cdot d^{-1}$, AFSSA 2006) was selected for the risk assessment of the sum of the 7 PBDE (BDE-28, $-47,-99,-100$, $-153,-154,-183)$ and of the 8 PBDE (7 PBDE + BDE-209). Health based guidance value for HBCDD has been established to $3000 \mathrm{ng} \cdot \mathrm{kg} \mathrm{bw}^{-1} \mathrm{~d}^{-1}$.

\section{$\underline{\text { Hexabromocyclododecane (HBCDD) }}$}

Mean vegetarian exposure to HBCDD was estimated at $0.04 \mathrm{ng} \cdot \mathrm{kg} \mathrm{bw}^{-1} \cdot \mathrm{d}^{-1}$ for LB hypothesis and 0.05 ng.kg bw ${ }^{-1} \cdot d^{-1}$ for UB hypothesis. At the $95^{\text {th }}$ percentile, exposure was $0.19 \mathrm{ng} \cdot \mathrm{kg} \mathrm{bw}^{-1} \cdot \mathrm{d}^{-1}$ (LB) and $0.21 \mathrm{ng} \cdot \mathrm{kg} \mathrm{bw}^{-1} \cdot \mathrm{d}^{-1}$ (UB). Main HBCDD contributors were fish for LB hypothesis (32.7\%) and oil for UB hypothesis $(27.3 \%)$. Mean and $95^{\text {th }}$ percentile exposure values to HBCDD are half those of the general French population. Based on the $\mathrm{BMDL}_{10}$ set at $3000 \mathrm{ng} \cdot \mathrm{kg} \mathrm{bw}^{-1} \mathrm{~d}^{-1}$ set by EFSA based on the neurodevelopmental effects on behaviour, the margin of exposure was higher than 10000 .

\section{Polybromobiphenyls (PBB)}

Mean vegetarian exposure to PBB was estimated at $0.00 \mathrm{ng} \cdot \mathrm{kg} \mathrm{bw}^{-1} \cdot \mathrm{d}^{-1}$ for LB hypothesis and 0.01 ng.kg bw $w^{-1} \cdot d^{-1}$ for UB hypothesis. At the $95^{\text {th }}$ percentile, exposure was $0.01 \mathrm{ng} \cdot \mathrm{kg} \mathrm{bw}^{-1} \cdot \mathrm{d}^{-1}$ (LB) and $0.02 \mathrm{ng} \cdot \mathrm{kg} \mathrm{bw}^{-1} \cdot \mathrm{d}^{-1}(\mathrm{UB})$. The margin of exposure calculated using the health based guidance value set by EFSA (0.15 mg.kg bw ${ }^{-1} \cdot \mathrm{d}^{-1}$, table 8) (Efsa, 2010a) was between $10^{6}$ and $10^{8}$.

\section{Polybromodiphenyleethers and 8 Polybromodiphenyleethers (PBDEs)}

Mean exposure of the vegetarian population to the sum of the 7 following PBDEs: BDE-28, $-47,-99$, $100,-153,-154$ and -183 was estimated at 0.11 ng.kg bw ${ }^{-1} \cdot \mathrm{d}^{-1}$ for LB hypothesis and 0.12 ng.kg bw ${ }^{1} \cdot d^{-1}$ for the UB hypothesis. At the $95^{\text {th }}$ percentile, exposure was $0.57 \mathrm{ng} \cdot \mathrm{kg} \mathrm{bw}^{-1} \cdot \mathrm{d}^{-1}$ for both hypotheses. Main contributors to the exposure of the 7-PBDEs were fish (LB: $47.9 \%$, UB: $45.2 \%$ ) and 


\section{ACCEPTED MANUSCRIPT}

mixed dishes (LB: 12.0\%, UB: 11.2\%). When adding BDE-209 to the sum of the 7 PBDEs, vegetarians had a mean exposure estimated at $0.25 \mathrm{ng} \cdot \mathrm{kg} \mathrm{bw}^{-1} \cdot \mathrm{d}^{-1}$ (LB) and $0.27 \mathrm{ng} \cdot \mathrm{kg} \mathrm{bw}^{-1} \cdot \mathrm{d}^{-1}$ (UB). At the $95^{\text {th }}$ percentile, exposure was $0.90 \mathrm{ng} \cdot \mathrm{kg} \mathrm{bw}^{-1} \cdot \mathrm{d}^{-1}$ (LB) and $0.093 \mathrm{ng} \cdot \mathrm{kg} \mathrm{bw}^{-1} \cdot \mathrm{d}^{-1}(\mathrm{UB})$. Main contributors to the exposure of the 8-PBDEs were fish (LB: $42.4 \%$, UB: $40.0 \%$ ) and mixed dishes (LB: $11.2 \%$, UB: $10.5 \%)$. Vegetarians are less exposed than the general French population, mean exposure values are nearly half those of the general population (Rivière et al., 2014). Considering the health based guidance value set by Afssa (10 ng.kg bw $\left.{ }^{-1} \cdot \mathrm{d}^{-1}\right)$, PBDEs are of no concern for the vegetarian population. The same conclusion was drawn when the risk was characterized using $\mathrm{BMDL}_{10}$ set by EFSA based on the effects on neurodevelopment for the following four congeners: BDE-47, $-53,-153$ and -209 (EFSA 2011, data not shown).

\section{Summary for POPs}

All exposure results to persistent organic pollutants were below those of the general population. There was a factor of ten between vegan and non-vegan exposure values to furans, dioxins and dl-PCBs on the one hand and to ndl-PCBs on the other hand. This was due to the strong contribution of fish and mollusks to the exposures of these compounds that are not consumed by the vegan population. No exceedance has been identified in the vegan subpopulation whereas within the general population, these substances were considered as "of-concern".

\section{Mycotoxins}

\section{Aflatoxins}

For the lower bound hypothesis (LB), mean exposure and exposure at the $95^{\text {th }}$ percentile to the sum of the aflatoxins were $0 \mathrm{ng} \cdot \mathrm{kg} \mathrm{bw}^{-1} \cdot \mathrm{d}^{-1}$. For the upper bound hypothesis (UB), mean exposure was 0.78 ng.kg bw ${ }^{-1} \cdot \mathrm{d}^{-1}$ and the $95^{\text {th }}$ percentile was $1.49 \mathrm{ng} \cdot \mathrm{kg} \mathrm{bw}^{-1} \cdot \mathrm{d}^{-1}$. Main contributors to the exposure of aflatoxins were bread and dried bread products (25.3\%) and rice and wheat products (14.3\%). $100 \%$ of the concentration data were below the limit of detection, these results are consequently only based on the UB hypothesis and have to be interpreted with caution.

Ochratoxin A (OTA) 


\section{ACCEPTED MANUSCRIPT}

For the LB hypothesis, mean exposure to OTA was estimated at $0.21 \mathrm{ng} \cdot \mathrm{kg} \mathrm{bw}^{-1} \cdot \mathrm{d}^{-1}$ and $0.54 \mathrm{ng} \cdot \mathrm{kg}$ $b w^{-1} \cdot d^{-1}$ at the $95^{\text {th }}$ percentile. For the upper bound hypothesis (UB), mean exposure was estimated at $1.9 \mathrm{ng} \cdot \mathrm{kg} \mathrm{bw}^{-1} \cdot \mathrm{d}^{-1}$ and $3.5 \mathrm{ng} \cdot \mathrm{kg} \mathrm{bw}^{-1} \cdot \mathrm{d}^{-1}$ at the $95^{\text {th }}$ percentile. Main contributors to the exposure of OTA were bread and dry baking for the lower bound hypothesis (LB: $78.4 \%)$ and fruits for the upper bound hypothesis (UB: $26.7 \%$ ). Considering the health based guidance value established by EFSA in 2010 (Efsa, 2010b), the exposure of the vegetarian population to ochratoxin $A$ is of no concern.

\section{Patulin (Pat)}

Mean exposure of the NutriNet Santé study population to patulin was estimated at $1.03 \mathrm{ng} \cdot \mathrm{kg} \mathrm{bw}^{-1} \cdot \mathrm{d}^{-1}$ for LB hypothesis and $29 \mathrm{ng} . \mathrm{kg} \mathrm{bw}^{-1} \cdot \mathrm{d}^{-1}$ for UB hypothesis. At the $95^{\text {th }}$ percentile, exposure was 4.17 $\mathrm{ng} \cdot \mathrm{kg} \mathrm{bw} w^{-1} \cdot \mathrm{d}^{-1}$ (LB) and $72 \mathrm{ng} \cdot \mathrm{kg} \mathrm{bw}^{-1} \cdot \mathrm{d}^{-1}(\mathrm{UB})$. Vegetarian exposure to Patulin was slightly higher than that in the general population. Main contributors to the exposure of patulin were fruits (LB: $35.5 \%$, UB: 57.8\%), cooked fruits and compotes (LB: $37.5 \%$, UB: $10.0 \%$ ) and cold drinks (LB: $24.2 \%$, UB: $23.4 \%$ ). The Scientific committee for food in 2000 (SCF) set a health based guidance value at 400 ng.kg bw ${ }^{1} \cdot d^{-1}$. Consequently, the exposure of the vegetarian population calculated in the present study is considered of no concern.

\section{Trichotecens}

Natural trichotecens are classified in different groups according to their chemical structure (groups A to C). Groups A and B are most commonly found in food. In group A, T-2 toxin and HT-2 toxin have been selected for the present study. In group B, nivalenol (NIV) and deoxynivalenol (DON) were studied. In 2002, SCF confirmed a health based guidance value of $60 \mathrm{ng} \cdot \mathrm{kg} \mathrm{bw}^{-1} \cdot \mathrm{d}^{-1}$ for the T-2 toxin and HT-2 toxin alone or combined, (JECFA 2001b). For DON, JECFA and the SCF had selected a health based guidance value of $1 \mu \mathrm{g} \cdot \mathrm{kg} \mathrm{bw}^{-1} \cdot \mathrm{d}^{-1}$ (Sirot et al. 2013). This value was confirmed by EFSA (Sirot et al. 2013). For NIV, the SCF set a health based guidance value of $0.7 \mu \mathrm{g} \cdot \mathrm{kg} \mathrm{bw}^{-1} \cdot \mathrm{d}^{-1}$ (SCF 2002).

\section{T-2 Toxin and HT-2 toxin}




\section{ACCEPTED MANUSCRIPT}

Considering the lower bound hypothesis, mean exposure to the sum of the aflatoxins was estimated at $9.33 \mathrm{ng} / \mathrm{kg}$ bw/day and $21.5 \mathrm{ng} \cdot \mathrm{kg} \mathrm{bw}^{-1} \cdot \mathrm{d}^{-1}$ at the $95^{\text {th }}$ percentile. For the upper bound hypothesis, mean exposure was $50 \mathrm{ng} \cdot \mathrm{kg} \mathrm{bw}^{-1} \cdot \mathrm{d}^{-1}$ and $99.6 \mathrm{ng} \cdot \mathrm{kg} \mathrm{bw}^{-1} \cdot \mathrm{d}^{-1}$ at the $95^{\text {th }}$ percentile. T2 and HT2 mycotoxins are therefore considered of concern. Main T2 and HT2 toxins contributors were pasta (LB: $32.5 \%$, UB: $20.7 \%$ ), bread and dried bread products (LB: $26.9 \%$, UB: $27.6 \%$ ) and rice and wheat products (LB: $15.2 \%$, UB: $13.7 \%)$.

\section{Deoxynivalenol (DON)}

Mean exposure of the vegetarian population to deoxynivalenol was estimated at $285 \mathrm{ng} \cdot \mathrm{kg} \mathrm{bw}^{-1} \cdot \mathrm{d}^{-1}$ for the LB hypothesis and $321 \mathrm{ng} \cdot \mathrm{kg} \mathrm{bw}^{-1} \cdot \mathrm{d}^{-1}$ for the UB hypothesis. At the $95^{\text {th }}$ percentile, exposure was $60.9 \mathrm{ng} \cdot \mathrm{kg} \mathrm{bw}^{-1} \cdot \mathrm{d}^{-1}$ (LB) and ng.kg bw ${ }^{-1} \cdot \mathrm{d}^{-1}$ (UB). Main contributors to the exposure of DON were sweet and savoury biscuits and bars (LB: $25.4 \%$, UB: $8.7 \%$ ), bread and dried bread products (LB: $10.4 \%$, UB: $28.1 \%$ ) and non-alcoholic flavoured drinks (LB: $6.1 \%$, UB: $14.7 \%$ ).

\section{Nivalenol (NIV)}

Mean exposure of the vegetarian population to nivalenol was estimated at $16.8 \mathrm{ng} \cdot \mathrm{kg} \mathrm{bw}^{-1} \cdot \mathrm{d}^{-1}$ for the LB hypothesis and $31.2 \mathrm{ng} \cdot \mathrm{kg} \mathrm{bw}^{-1} \cdot \mathrm{d}^{-1}$ for the UB hypothesis. At the $95^{\text {th }}$ percentile, exposure was 51.3 $\mathrm{ng} \cdot \mathrm{kg} \mathrm{bw}^{-1} \cdot \mathrm{d}^{-1}$ (LB) and $70.6 \mathrm{ng} \cdot \mathrm{kg} \mathrm{bw}^{-1} \cdot \mathrm{d}^{-1}(\mathrm{UB})$. Main contributors to the exposure of NIV were rice and wheat products (LB: $33.3 \%$, UB: $22.8 \%$ ), pasta (LB: $25.2 \%$, UB: $20.8 \%$ ) and bread and dried bread products (LB: $22.4 \%$, UB: $22.5 \%)$.

\section{Zearalenone (ZER)}

In 2000, the SCF established a temporary TDI of $0.2 \mu \mathrm{g} \cdot \mathrm{kg} \mathrm{bw}^{-1} \cdot \mathrm{d}^{-1}$ (Sirot et al. 2013). For the lower bound hypothesis, mean exposure to zearaleone was estimated at $5.66 \mathrm{ng} \cdot \mathrm{kg} \mathrm{bw}^{-1} \cdot \mathrm{d}^{-1}$ and $11.2 \mathrm{ng} \cdot \mathrm{kg}$ $b w^{-1} \cdot d^{-1}$ at the $95^{\text {th }}$ percentile. For the upper bound, mean exposure was $26 \mathrm{ng} \cdot \mathrm{kg} \mathrm{bw}^{-1} \cdot \mathrm{d}^{-1}$ and 45.3 ng.kg bw ${ }^{-1} \cdot d^{-1}$ at the $95^{\text {th }}$ percentile. Main contributors to the exposure of zearalenone were bread and dried bread products (LB: $32.0 \%$, UB: $23.2 \%$ ) and pasta (LB: $16.3 \%$, UB: $12.0 \%$ ).

\section{Fumonisins}


The JECFA established a health based guidance value of $2 \mu \mathrm{g} \cdot \mathrm{kg} \mathrm{bw}^{-1} \cdot \mathrm{d}^{-1}$ for the group of fumonisins FB1 and B2 individually or in combination (JECFA 2001b). Considering the lower bound hypothesis, mean exposure to FB1 was $8.9 \mathrm{ng} \cdot \mathrm{kg} \mathrm{bw}^{-1} \cdot \mathrm{d}^{-1}$ and $12.5 \mathrm{ng} \cdot \mathrm{kg} \mathrm{bw}^{-1} \cdot \mathrm{d}^{-1}$ at the $95^{\text {th }}$ percentile. Considering the upper bound hypothesis, mean exposure was $26 \mathrm{ng} \cdot \mathrm{kg} \mathrm{bw}^{-1} \cdot \mathrm{d}^{-1}$ and $63.9 \mathrm{ng} \cdot \mathrm{kg} \mathrm{bw}^{-1} \cdot \mathrm{d}^{-}$ ${ }^{1}$ at the $95^{\text {th }}$ percentile. Mean exposure to FB2 was estimated at $2.4 \mathrm{ng} \cdot \mathrm{kg} \mathrm{bw}^{-1} \cdot \mathrm{d}^{-1}$ for the LB hypothesis and 13 ng.kg bw ${ }^{-1} \cdot d^{-1}$ for the UB hypothesis. At the $95^{\text {th }}$ percentile, exposure was 12.5 ng.kg bw ${ }^{-1} \cdot d^{-1}\left(\right.$ LB) and $32.6 \mathrm{ng} \cdot \mathrm{kg} \mathrm{bw}^{-1} \cdot \mathrm{d}^{-1}$ (UB). Main contributors to the exposure to fumonisins were salty or sweet and savoury biscuits and bars (LB: 50.7\%, UB: 13.9\%), bread and dried bread products (LB: $20.7 \%$, UB: $30.9 \%)$ and non-alcoholic flavoured drinks (LB: $12.3 \%$, UB: $29.5 \%$ ).

\section{Summary for mycotoxins}

For most of the mycotoxins included in the study, vegetarian population had exposures close to those previously reported for the general population except for T2/HT2 toxins for which mean exposures values were 1.2 (LB) to 2.5 -fold (UB) higher than those in the general population. Percentage of the population exceeding the respective health based guidance values of DON and T2/HT2 toxins were in the same order of magnitude for both the vegetarian and the general populations. The risk could not be excluded for both substances. On the other hand, the risk could be excluded for the other studied mycotoxins.

\section{Phytoestrogens}

Main phytoestrogens belong to the classes of isoflavones, coumestans and lignans:

- isoflavones include genistein and biochanin A, daidzein, formononetin and glycitein

- lignans include matairesinol and secoisolaricirecinol

- coumestans primarily include coumestrol

Overall mean exposure to isoflavones, coumestrol and equol ranged from $0.199 \mathrm{mg} \cdot \mathrm{kg} \mathrm{bw}^{-1} \cdot \mathrm{d}^{-1}$ (LB) to $0.201 \mathrm{mg} \cdot \mathrm{kg} \mathrm{bw}^{-1} \cdot \mathrm{d}^{-1}(\mathrm{UB})$. At the $95^{\text {th }}$ percentile, exposure ranged from $0.799 \mathrm{mg} \cdot \mathrm{kg} \mathrm{bw}^{-1} \cdot \mathrm{d}^{-1}(\mathrm{LB})$ to 
$0.803 \mathrm{mg} \cdot \mathrm{kg} \mathrm{bw}^{-1} \cdot \mathrm{d}^{-1}$ (UB). Main contributors were food for particular uses (LB: $37.6 \%$, UB: $32.0 \%$ ), desserts and dairy-based desserts (LB: $24.9 \%$, UB: 12.7\%) and vegetables (excluding potatoes) (LB: 7.2\%, UB: $22.4 \%)$.

With regards to phytoestrogens, exposures of the vegetarian population were far above those reported for the general population (10 to 300 times higher). Overall exposure was mainly due to isoflavone and to a smaller extent to coumestrol and equol. Consumption rate of "food for particular uses (energy drinks, meal substitutes, etc.) " was $50 \%$ instead of $12 \%$ in the general French population. The quantity of food consumed from that category was 6 times higher in the vegetarian population compared to that for the general French population. "Food for particular uses" category was the main contributor of phytoestrogens exposure in vegetarian population.

Clarke et al (2003) reported an average algycine daily intake of $10.5 \mathrm{mg} \cdot \mathrm{d}^{-1}$ for a vegetarian population in the United-Kingdom.

\section{Acrylamide}

Mean exposure of the vegetarian population to acrylamide was estimated at $0.32 \mu \mathrm{g} \cdot \mathrm{kg} \mathrm{bw}^{-1} \cdot \mathrm{d}^{-1}$ for the LB hypothesis and $0.33 \mu \mathrm{g} \cdot \mathrm{kg} \mathrm{bw}^{-1} \cdot \mathrm{d}^{-1}$ for the UB hypothesis. At the $95^{\text {th }}$ percentile, exposure was 1.03 $\mu \mathrm{g} \cdot \mathrm{kg} \mathrm{bw}^{-1} \cdot \mathrm{d}^{-1}$ (LB \& UB). Main acrylamide contributors were potatoes (LB: $34.6 \%$, UB: $34.1 \%$ ), salty or sweet crackers and bars (LB: $20.6 \%$, UB: $20.3 \%$ ) and coffee (LB: $19.6 \%$, UB: $19.3 \%$ ).

The JECFA identified two BMDL ${ }_{10}$ values for acrylamide based on carcinogenicity, on the basis of two separate effects:

- $\quad 0.18 \mathrm{mg} \cdot \mathrm{kg} \mathrm{bw}^{-1} \cdot \mathrm{d}^{-1}$ (onset of Harderian gland tumours in mice)

- $\quad 0.31 \mathrm{mg} \cdot \mathrm{kg} \mathrm{bw}^{-1} \cdot \mathrm{d}^{-1}$ (onset of mammary tumours in rats)

The margins of exposure for $\mathrm{BMDL}_{10}$ of 310 and $180 \mu \mathrm{g} \cdot \mathrm{kg} \mathrm{bw}^{-1} \cdot \mathrm{d}^{-1}$ were respectively 955 and 554 for average exposure and 302 and 175 for $95^{\text {th }}$ percentile (Table 9). The calculated margins of exposure were much lower than 10000 and consequently, considering that acrylamide is genotoxic, the risk due to acrylamide dietary exposure could not be excluded. 


\section{ACCEPTED MANUSCRIPT}

\section{Polycyclic aromatic hydrocarbons (PAH)}

\section{PAH 4}

Mean exposure of the vegetarian population to PAH4 was estimated to $1.02 \mu \mathrm{g} \cdot \mathrm{kg} \mathrm{bw}^{-1} \cdot \mathrm{d}^{-1}$ for LB hypothesis and $1.14 \mu \mathrm{g} \cdot \mathrm{kg} \mathrm{bw}^{-1} \cdot \mathrm{d}^{-1}$ for UB hypothesis. At the $95^{\text {th }}$ percentile, exposure was $2.26 \mu \mathrm{g} . \mathrm{kg}$ $\mathrm{bw}^{-1} \cdot \mathrm{d}^{-1}$ (LB) and $2.39 \mu \mathrm{g} \cdot \mathrm{kg} \mathrm{bw}^{-1} \cdot \mathrm{d}^{-1}(\mathrm{UB})$. Main contributors to dietary exposure of polycyclic aromatic hydrocarbons (sum of the four) were bread and dried bread products (LB: $30.1 \%$, UB: $29.1 \%$ ) and oil (LB: $22.4 \%$, UB: $19.9 \%)$.

\section{PAH 11}

For the lower bound hypothesis, mean exposure of the vegetarian population to PAH 11 was 0.22 ng.kg bw ${ }^{-1} \cdot d^{-1}$ and $0.55 \mathrm{ng} \cdot \mathrm{kg} \mathrm{bw}^{-1} \cdot \mathrm{d}^{-1}$ at the $95^{\text {th }}$ percentile. Considering the upper bound hypothesis, mean exposure was $0.44 \mathrm{ng} \cdot \mathrm{kg} \mathrm{bw}^{-1} \cdot \mathrm{d}^{-1}$ and $0.89 \mathrm{ng} \cdot \mathrm{kg} \mathrm{bw}^{-1} \cdot \mathrm{d}^{-1}$ at the $95^{\text {th }}$ percentile. Main contributors were bread and dry baking products (LB: $47.5 \%$, UB: $32.2 \%$ ), Viennese pastry (LB: 15.1\%, UB: $9.0 \%)$.

Margin of exposure for PAH4 was calculated using the $\mathrm{BMDL}_{10}$ of $0.34 \mathrm{mg} \cdot \mathrm{kg} \mathrm{bw}^{-1} \cdot \mathrm{d}^{-1}$ (set by EFSA based on carcinogenicity (2008c), and was above 100000 (table 10). Exposure of PAH11 was below the virtually safe dose set up by RIVM (Baars et al., 2001). Consequently, considering PAH4 and PAH11 and their respective health-based guidance values, dietary exposure to these compounds is not of concern for the studied vegetarian population.

\section{Conclusion}

Exposures to pesticides were not calculated in the present study. The reason being that available contamination data were generated not taking into account the organic or non-organic origins of the food items. Indeed, the vegetarian population of the Nutrinet-Santé study seemed to consume a large part of organic food (Baudry et al., 2015; Baudry et al., 2016) that could be less contaminated than conventional food. For example, a first study among participants of the BioNutrinet-Santé study highlighted that vegetarian or vegan participants had a share of organic food of nearly $50 \%$. The study 
gathering the contamination data used in the present article did not take into account this type of product, therefore the dietary exposure to chemicals reported in the present study could be overestimated. Further studies using complementary data about chemical composition of organic food could overcome this limitation. Consumption data collected for the present study were based on a voluntary basis through the internet. Individuals who completed the study should therefore have access to computer. This mode of data collection could have an impact on the representativeness of the studied population. On the one hand, the data collection is on a voluntary basis. So only volunteers interested by the questions related to health and nutrition answer to the questionnaires. On the other hand, because an internet connection is required, persons with no internet connection, and probably some elderly, are excluded.

Nevertheless, the results presented in the present study allow to draw conclusions with regards to the exposure of the vegetarian populations to dietary contaminants.

For some contaminants considered in the present study, some differences of the exposure appeared between the vegetarian and the French general populations. Exposures to phytoestrogens, some mycotoxins (T2 and $\mathrm{HT} 2$ toxins) and some TEM (Cd, $\mathrm{Al}, \mathrm{Sn}, \mathrm{Ni})$ were higher in the vegetarian population compared to those in the general population.

Among the vegetarian population, main contributor to phytoestrogens appeared to be "foods for particular nutritional uses". These products are consumed by a larger part of vegetarian population (50\% instead of $12 \%$ within the general population) and in higher amount: six times more than the general French population. Concerning exposure to isoflavones, the risk could not be excluded. Mycotoxins showed a high exposure to T2-HT2 toxin and patuline. One of the main contributors to T2 and HT2 toxins exposure was the "rice \& wheat" food category. Food items in this category were consumed on average in quantities two times higher in the vegetarian population than in the general population. For vegetarians, exposure to patuline was mostly due to fruits, cooked fruits and compotes and non-alcoholic flavoured drinks. Consumption level of these contributors are higher in the vegetarian population. Higher exposure to tin, nickel, cadmium, as well as to aluminum was demonstrated in the vegetarian population compared to the general population. High consumption of fruits and vegetables (cooked, raw and dry) in the vegetarian population appeared to be the reason for this observation.

The vegetarian population studied in the present study was, however, less exposed than the general population to some contaminants. This was true for several persistent organic pollutants; PAHs; 
acrylamide; some mycotoxins (NIV, DON and aflatoxins) and some TEM (As, $\mathrm{Ca} \mathrm{Mg}, \mathrm{Cu}, \mathrm{Na}, \mathrm{Fe}$ ). Main contributors to the exposure of POP were "fish" and "crustaceans and mollusks". These categories were consumed by $30 \%$ of the vegetarian population compared to $80 \%$ in the French general population (Anses 2011). Among the vegan population, no exceedances of the respective health based guidance values were described. Bread and dried bread products were the main contributors to PAHs (HAP4 and HAP11), certain TEM (Mg, Na and Fe) and certain mycotoxins (DON and Niv) dietary exposures. Foods in this category were consumed by fewer vegetarians and in smaller amounts than that in the general population. This explained the differences of the exposure between the vegetarian and the general populations. Potatoes consumption had a much lower consumption rate on average in the vegetarian population compared to the non-vegetarian population which might explain the lower dietary exposure to acrylamide of the vegetarian population compared to the general population. The lower consumption of coffee, cheese, fish lowered $\mathrm{Cu}, \mathrm{Ca}$ and $\mathrm{As}$ exposures. Lastly, exposure to some substances did not appear to be dramatically different between vegetarian and non-vegetarian populations. This is the case for $\mathrm{Pb}, \mathrm{Hg}$ and some mycotoxins (fumonisins, OTA) that showed exposure similar to those previously reported for the general population.

In conclusion, despite some limitations due to the way the consumption data were gathered and to the fact that the contamination data generated in the context of the study not specifically focusing on the vegetarian populations, the present study highlights that the exposure pattern of the vegetarian population to contaminants is dramatically different than that reported for the general population. 


\section{References}

Afssa, 2006. Avis de l'Agence française de sécurité sanitaire des aliments relatif à l'évaluation des risques liés à la présence de retardateurs de flamme bromés dans les aliments. Afssa, Maisons Alfort,

\section{France}

Akhandaf Y. De Henauw S. Dofkova M. Ruprich J. Papadopoulos A. Sirot V. Kennedy M.C. Pinchen H. Blume K. Lindtner O. Brantsaeter A.L. Meltzer H.M. Sioen I., 2014. Food Additives \& Contaminants: Part A. Taylor \& Francis.

Arnault N, Caillot L, Castetbon K, et al., 2013. Table de composition des aliments, étude NutriNetSanté. [Food composition table, NutriNet-Santé study]. Paris: Les éditions INSERM/Economica.

Baars A.J., Theelen R.M.C., Janssen P.J.C.M., Hesse J.M., van Apeldoorn M.E.,Meijerink M.C.M., Verdam L. and Zeilmaker M.J., (2001) - Re-evaluation of human-toxicological maximum permissible risk levels RIVM, Rijsinstituut voor volksgezondheid en milieu. Report 711701025.

Baudry J, Méjean C, Allès B, et al. Contribution of Organic Food to the Diet in a Large Sample of French Adults (the NutriNet-Santé Cohort Study). Nutrients. 2015;7(10):8615-8632. doi:10.3390/nu7105417.

Baudry J, Touvier M, Allès B, et al., 2016. Typology of eaters based on conventional and organic food consumption: results from the NutriNet-Santé cohort study. $\mathrm{Br} J$ Nutr.1-10. doi:10.1017/S0007114516002427.

Black AE, 2000. Critical evaluation of energy intake using the Goldberg cut-off for energy intake:basal metabolic rate. A practical guide to its calculation, use and limitations. Int J Obes Relat Metab Disord; 24:1119-1130.

Clarke DB, Barnes KA, Castle L, Rose M, Wilson LA, Baxter MJ, Price KR, DuPont MS, 2003. Levels of phytoestrogens, inorganic trace-elements, natural toxicants and nitrate in vegetarian duplicate diets, Food Chemistry, 81: 287-300 


\section{ACCEPTED MANUSCRIPT}

Craig CL, Marshall AL, Sjostrom M, et al, 2003. International physical activity questionnaire: 12country reliability and validity. Med Sci Sports Exerc ;35:1381-1395.

Coudray C, 2001. Cuivre. In 'Apports nutritionnels conseillés pour la population française, 3rd edition.' Ed.Tec\&Doc. pp. 158-161. (Lavoisier : Paris, France)

Dubuisson C, Lioret S, Touvier M, Dufour A, Calamassi-Tran G, Volatier JL, et al., 2010. Trends in food and nutritional intakes of French adults from 1999 to 2007: results from the INCA surveys. $\mathrm{Br} \mathrm{J}$ Nutr;103(7):1035-48.

EFSA, 2008a). Safety of aluminium from dietary intake. Scientific Opinion of the Panel on Food Additives, Flavourings, Processing Aids and Food Contact Materials (AFC). Parma, Italy.

EFSA, 2008b. Scientific Opinion of the Panel on Contaminants in the Food chain. Perfluorooctane sulfonate (PFOS), perfluorooctanoic acid (PFOA) and their salts (Question No EFSA-Q-2004-163) . EFSA, Parma, Italy.

Efsa, 2008c. Scientific Opinion of the Panel on Contaminants in the Food chain on a request from the European Commission on polycyclic aromatic hydrocarbons in food. Efsa, Parma, Italy.

EFSA, 2009. Cadmium in food. Scientific Opinion of the Panel on Contaminants in the Food Chain. Parma, Italy, EFSA. 980.

EFSA, 2010a. Scientific Opinion on Polybrominated Biphenyls (PBBs) in Food. Available at: http://www.efsa.europa.eu/fr/scdocs/doc/1789.pdf. EFSA Journal. Parma, Italy, EFSA. 8: 1789.

EFSA, 2010b. Scientific opinion. Statement on recent scientific information on the toxicity of Ochratoxin A1

EFSA, 2011. Scientific Opinion on Polybrominated Diphenyl Ethers (PBDEs) in Food. EFSA Panel on Contaminants in the Food Chain (CONTAM). Parma, Italy, EFSA. 9. 


\section{ACCEPTED MANUSCRIPT}

EFSA, 2012. Scientific Opinion on Lead in Food. Scientific opinion. E. p. o. C. i. t. F. C. (CONTAM). Parma, Italy, European Food Safety Authority (EFSA). 8.

EFSA, 2015. Scientific Opinion on the risks to public health related to the presence of nickel in food and drinking water. Parma, Italy, EFSA. 13.

Fox N. Ward K., 2008. Health, ethics and environment A qualitative study of vegetarian motivations. Appetite 50

Guéguen L, 2001. Calcium . In 'Apports nutritionnels conseillés pour la population française, 3rd edition’ Ed . Tec\&Doc . pp . 131-140 . (Lavoisier : Paris, France)

Guillocheau E., 2013 Etude de l'exposition des populations végétariennes aux substances chimiques identifiées dans le cadre de l'EAT 2.

Hercberg S. Castetbon K. Czernichow S. Malon A. Mejean C Kesse E. Touvier M. and Galan P., 2010. The Nutrinet-Santé Study: a web-based prospective study on the relationship between nutrition and health and determinants of dietary patterns and nutritional status - BMC Public Health.

JECFA, 2001a. Joint FAO/WHO Expert Committee on Food Additives.Summary and conclusions of the Fifty-seventh meeting, Rome, 5-14 June 2001

JECFA, 2001b. Safety evaluation of certain mycotoxins in food prepared by the fifty-sixth meeting of the Joint FAO/WHO Expert Committee on Food Additives. WHO Food Additives Series 47.

Kalonji E, Sirot V, Noël L, Guérin T, Margaritis I, Leblanc JC., 2015. Nutritional Risk Assessment of Eleven Minerals and Trace Elements: Prevalence of Inadequate and Excessive Intakes from the Second French Total Diet Study. Eur J Nutr \& Food Safety 5(4): 281-296.

Kahleova H. Pelikanova T., 2015. Vegetarian Diets in the Prevention and Treatment of Type 2 Diabetes. The journal of the American college of nutrition.

Lassale C, Peneau S, Touvier M, et al., 2013. Validity of web-based self-reported weight and height: results of the Nutrinet-Sante study. J Med Internet Res ;15:e152. 


\section{ACCEPTED MANUSCRIPT}

Lassale C, Castetbon K, Laporte F, et al., 2015. Validation of a Web-based, self-administered, nonconsecutive-day dietary record tool against urinary biomarkers. Br J Nutr ;113:953-962.

Lassale C, Castetbon K, Laporte F, et al., 2016. Correlations between Fruit, Vegetables, Fish, Vitamins, and Fatty Acids Estimated by Web-Based Nonconsecutive Dietary Records and Respective Biomarkers of Nutritional Status. J Acad Nutr Diet ;116:427-438.

Leblanc J-C. Yoon H. Kombadjian A. Verger P., 2000. Nutritional intakes of vegetarian populations in France. European Journal of Clinical Nutrition.

Mariotti F, 2017. Vegetarian and plant-based diets in health and disease prevention.887 pages.

Rivière G. Sirot V. Tard A. Jean J. Marchand P. Veyrand B. Le Bizec B. Leblanc J.C., 2014. Food risk assessment for perfluoroalkyl acids and brominated flame retardants in the French population: Results fromthe second French total diet study. Science of the Total Environment 491-492.

Sirot V. Volatier J.L. Calamassi-Tran G. Dubuisson C. Ménard C. Dufour A. Leblanc J.C., 2009. Core food of the French food supply: second Total Diet Study. Food Additives \& Contaminants: Part A Sirot V, Tard A, Venisseau A, Brosseaud A, Marchand P, Le Bizec B, Leblanc JC., 2012a. Dietary exposure to polychlorinated dibenzo-p-dioxins, polychlorinated dibenzofurans and polychlorinated biphenyls of the French population: Results of the second French Total Diet Study. Chemosphere 88: 492-500.

Sirot V, Hommet F, Tard A, Leblanc JC., 2012b. Dietary acrylamide exposure of the French population: results of the Second French Total Diet Study. Food Chem Tox 50: 889-94.

Sirot V, Fremy JM, Leblanc JC., 2013. Dietary exposure to mycotoxins and health risk assessment in the second French total diet study. Food Chem Tox 52: 1-11.

Touvier M, Mejean C, Kesse-Guyot E, et al., 2010 Comparison between web-based and paper versions of a self-administered anthropometric questionnaire. Eur J Epidemiol ;25:287-296. 


\section{ACCEPTED MANUSCRIPT}

Touvier M, Kesse-Guyot E, Mejean C, et al., 2011. Comparison between an interactive web-based self-administered $24 \mathrm{~h}$ dietary record and an interview by a dietitian for large-scale epidemiological studies. Br J Nutr ;105:1055-1064.

Vergnaud AC, Touvier M, Mejean C, et al., 2011. Agreement between web-based and paper versions of a socio-demographic questionnaire in the NutriNet-Sante study. Int J Public Health ;56:407-417.

Veyrand B, Sirot V, Pollono C, Marchand P, Dervilly-Pinel G, Tard A, Leblanc JC, Le Bizec B., 2013. Human dietary exposure to polycyclic aromatic hydrocarbons: results of the second French Total Diet Study. ;54:11-7.

WHO, 1955. Second workshop on reliable evaluation of low-level contamination of food. Report on a workshop in the frame of GEMS-Food Euro, Kulmbach, 26-27 May 1995. Rome: World Health Organization Regional Office for Europe, GEMS/FoodEURO. 


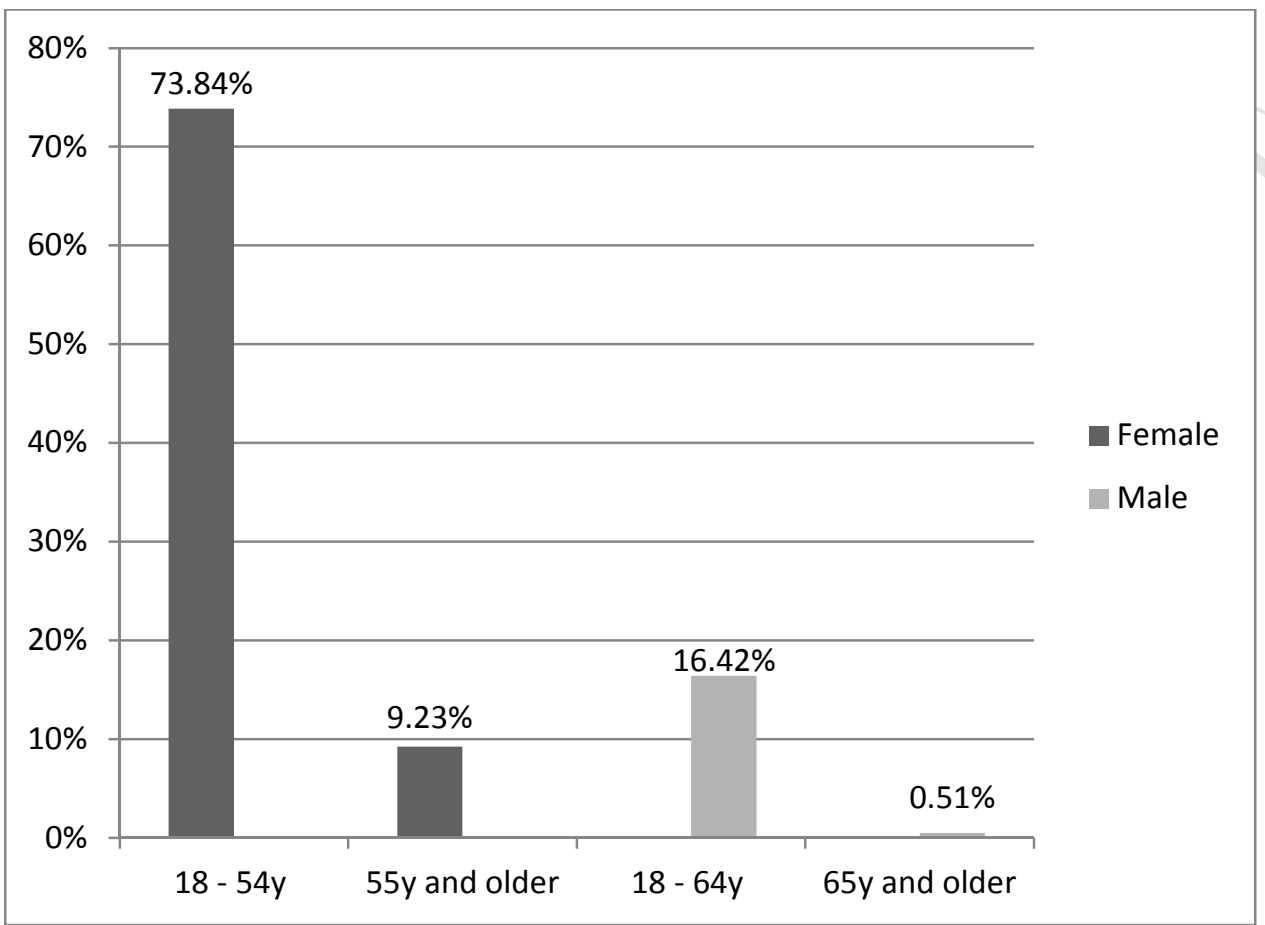

Figure 1: Age distribution by gender (\%) in the vegetarian population of the NutriNet-Santé study

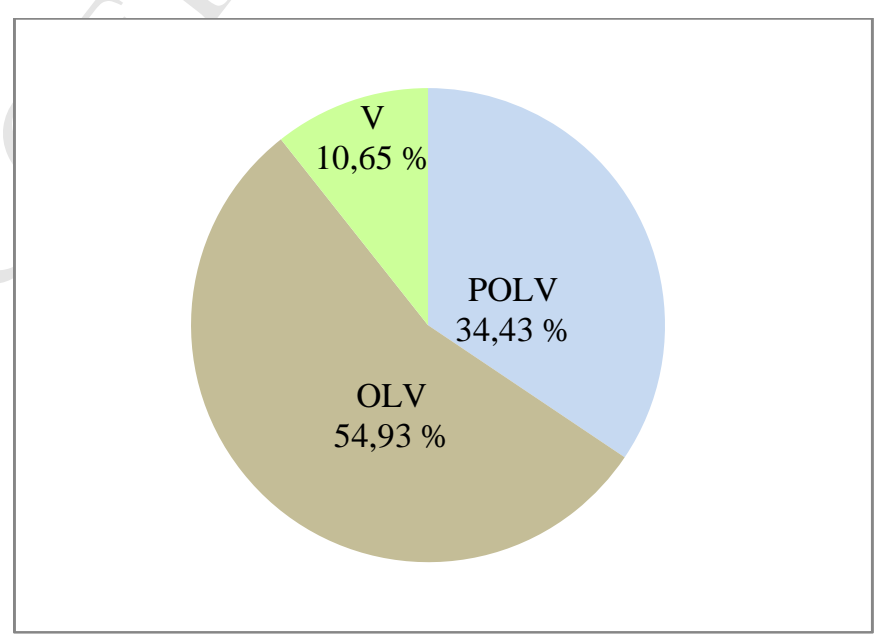

V: Vegan, OLV : Ovo-lacto vegetarian, POLV : Pesco-ovo-lacto vegetarian 
Figure 2: Distribution of the different vegetarian diet categories (\%) in the NutriNet-santé study population 
Table 1: Mean and Standard deviation (SD) of age (years) and BMI (kg. $\mathbf{m}^{-2}$ )

\begin{tabular}{|l|c|c|c|c|}
\cline { 2 - 5 } \multicolumn{1}{c|}{} & $\mathbf{n}$ & Min & Mean $\mathbf{\pm s d}$ & Max \\
\hline Age $(\mathrm{y})$ & 1766 & 18.0 & $36.6 \pm 12,9$ & 81.0 \\
\hline BMI $\left(\mathrm{kg} / \mathrm{m}^{2}\right)$ & 1766 & 13.3 & $21.6 \pm 3.7$ & 45.3 \\
\hline
\end{tabular}


Table 2. Food consumption in the NutriNet-Santé study vegetarian and in the general French populations

\begin{tabular}{|c|c|c|c|c|c|c|c|}
\hline \multirow[b]{2}{*}{ Food groups } & \multicolumn{5}{|c|}{ NutriNet-Santé study Vegetarian populations } & \multicolumn{2}{|c|}{ French general population (Dubuisson et al., 2010) } \\
\hline & $\mathrm{n}$ & $\begin{array}{c}\text { Consumers rate } \\
(\%)\end{array}$ & $\begin{array}{l}\text { Mean } \\
\left(g \cdot d^{-1}\right)\end{array}$ & $\begin{array}{c}\text { Std } \\
\left(g \cdot d^{-1}\right)\end{array}$ & $\begin{array}{c}\text { 95th perc. } \\
\left(\text { g. } d^{-1}\right)\end{array}$ & $\begin{array}{c}\text { Consumers rate } \\
(\%)\end{array}$ & $\begin{array}{l}\text { Mean } \\
\left(g \cdot d^{-1}\right)\end{array}$ \\
\hline $\begin{array}{c}\text { Bread and dried bread } \\
\text { products }\end{array}$ & 1651 & 93.5 & 82.7 & 65.3 & 204 & 98.5 & 115 \\
\hline Breakfast cereals & 654 & 37 & 13.2 & 24.4 & 66.7 & 16.8 & 4.9 \\
\hline Pasta & 997 & 56.5 & 39.7 & 51.4 & 144 & 77.4 & 37.8 \\
\hline Rice and wheat products & 1116 & 63.2 & 40.2 & 51.6 & 133.3 & 64.4 & 24.7 \\
\hline Other cerelas & 353 & 20 & 5.1 & 17 & 33.3 & 2.7 & 0.5 \\
\hline Croissant-like pastries & 359 & 20.3 & 5.7 & 16.5 & 35 & 46.2 & 11.8 \\
\hline $\begin{array}{l}\text { Sweet and savoury biscuits } \\
\text { and bars }\end{array}$ & 952 & 53.9 & & 23.8 & 60 & 57.1 & 9 \\
\hline Pastries and cakes & 1040 & 58.9 & 35.5 & 50.5 & 138.3 & 76.1 & 37.5 \\
\hline Milk & 958 & 54.2 & 80 & 121 & 333.3 & 50.1 & 85.7 \\
\hline Ultra fresh dairy products & 1228 & 69.5 & 75 & 94.6 & 250 & 83 & 81.9 \\
\hline Cheese & 1121 & 63.5 & 23.9 & 31.1 & 80 & 91.9 & 33.4 \\
\hline Eggs and egg products & 582 & 33 & 8.1 & 15.3 & 33.3 & 63.9 & 15.3 \\
\hline
\end{tabular}




\begin{tabular}{|c|c|c|c|c|c|c|c|}
\hline \multirow[b]{2}{*}{ Food groups } & \multicolumn{5}{|c|}{ NutriNet-Santé study Vegetarian populations } & \multicolumn{2}{|c|}{ French general population (Dubuisson et al., 2010) } \\
\hline & $\mathrm{n}$ & $\begin{array}{c}\text { Consumers rate } \\
(\%)\end{array}$ & $\begin{array}{l}\text { Mean } \\
\left(g^{\left.-d^{-1}\right)}\right.\end{array}$ & $\begin{array}{l}\text { Std } \\
(\text { g.d-1) }\end{array}$ & $\begin{array}{c}\text { 95th perc. } \\
\text { (g.d-1) }\end{array}$ & $\begin{array}{c}\text { Consumers rate } \\
(\%)\end{array}$ & $\begin{array}{l}\text { Mean } \\
(\text { g.d-1) }\end{array}$ \\
\hline Butter & 673 & 38.1 & 3.1 & 6.1 & 16 & 81.7 & 11 \\
\hline Oil & 1285 & 72.8 & 8.5 & 10.5 & 28.8 & 84.7 & 10.7 \\
\hline Margarine & 407 & 23 & 1.9 & 5.4 & 10.8 & 40.7 & 4.4 \\
\hline Other fats & 83 & 4.7 & 0.5 & 2.8 & 0 & 2.8 & 0.1 \\
\hline Meat & 0 & 0 & 0 & 31.5 & 81.7 & 92 & 49.7 \\
\hline Poultry and game & 0 & 0 & 0 & 11.1 & 15 & 75.6 & 31.9 \\
\hline Offals & 0 & 0 & 0 & 177.2 & 537.1 & 16 & 2.9 \\
\hline Delicatessen meats & 0 & 0 & 0 & 51.1 & 133.3 & 91.1 & 34.3 \\
\hline Fish & 516 & 29.2 & 14.6 & 49.1 & 133.3 & 79.3 & 26.5 \\
\hline Crustaceans and molluscs & 156 & 8.8 & 2.5 & 242.5 & 612 & 33.5 & 4.5 \\
\hline $\begin{array}{c}\text { Vegetables (excluding } \\
\text { potatoes) }\end{array}$ & 1737 & 98.4 & 240.2 & 34.7 & 77.3 & 98.9 & 139.3 \\
\hline Potatoes potato products & 948 & 53.7 & 35.2 & 21.3 & 50 & 90.6 & 58.3 \\
\hline Pulses & 905 & 51.2 & 32.1 & 16.8 & 41.7 & 29.7 & 9.7 \\
\hline Fruits & 1639 & 92.8 & 225.1 & 18.8 & 50 & 87 & 144.4 \\
\hline Dried fruits, nuts and seeds & 1184 & 67 & 19.8 & 475.5 & 1550 & 31.3 & 2.7 \\
\hline
\end{tabular}




\begin{tabular}{|c|c|c|c|c|c|c|c|}
\hline \multirow[b]{2}{*}{ Food groups } & \multicolumn{5}{|c|}{ NutriNet-Santé study Vegetarian populations } & \multicolumn{2}{|c|}{ French general population (Dubuisson et al., 2010) } \\
\hline & $\mathrm{n}$ & $\begin{array}{c}\text { Consumers rate } \\
(\%)\end{array}$ & $\begin{array}{l}\text { Mean } \\
\left(\mathrm{g} \cdot \mathrm{d}^{-1}\right)\end{array}$ & $\begin{array}{c}\text { Std } \\
\left(g \cdot d^{-1}\right)\end{array}$ & $\begin{array}{l}\text { 95th perc. } \\
\left(g^{\left.-d^{-1}\right)}\right.\end{array}$ & $\begin{array}{c}\text { Consumers rate } \\
(\%)\end{array}$ & $\begin{array}{l}\text { Mean } \\
\left(\mathrm{g} \cdot \mathrm{d}^{-1}\right)\end{array}$ \\
\hline Edible ice & 337 & 19.1 & 7.5 & 190.3 & 485 & 32.5 & 8.7 \\
\hline Chocolate & 1025 & 58 & 9.5 & 140.2 & 293.8 & 48.2 & 5.7 \\
\hline Sugar and sugar derivatives & 1309 & 74.1 & 14.5 & 183.9 & 478 & 85.3 & 20.6 \\
\hline Drinking water & 1699 & 96.2 & 648.6 & 414.3 & 1133.3 & 95.7 & 788.6 \\
\hline $\begin{array}{l}\text { Non-alcoholic flavoured } \\
\text { drinks }\end{array}$ & 1424 & 80.6 & 155.5 & 40.1 & 113.3 & 71.8 & 139.8 \\
\hline Alcoholic drinks & 740 & 41.9 & 62.6 & 8.4 & 2.1 & 71.2 & 154.8 \\
\hline Coffee & 979 & 55.4 & 109.9 & 116.9 & 333.3 & 80 & 253.2 \\
\hline Hot beverages & 1417 & 80.2 & 346.9 & 71 & 200 & 59.6 & 129.5 \\
\hline $\begin{array}{c}\text { Pizzas, quiches, savoury } \\
\text { pastries and cakes }\end{array}$ & 667 & 37.8 & 23.6 & 67.4 & 166.7 & 51.7 & 23.2 \\
\hline Sandwiches and snacks & 90 & 5.1 & 1.5 & 37.2 & 100 & 36.9 & 16.5 \\
\hline Soups and broths & 843 & 47.7 & 78.5 & 19.4 & 56.5 & 52.4 & 86.1 \\
\hline Mixed dishes & 1282 & 72.6 & 63.1 & 64.5 & 67.5 & 84.7 & 69.1 \\
\hline $\begin{array}{l}\text { Desserts and dairy-based } \\
\text { desserts }\end{array}$ & 905 & 51.2 & 38 & 50.5 & 133.3 & 52.1 & 25.2 \\
\hline
\end{tabular}




\begin{tabular}{|c|c|c|c|c|c|c|c|}
\hline \multirow[b]{2}{*}{ Food groups } & \multicolumn{5}{|c|}{ NutriNet-Santé study Vegetarian populations } & \multicolumn{2}{|c|}{ French general population (Dubuisson et al., 2010) } \\
\hline & $\mathrm{n}$ & $\begin{array}{c}\text { Consumers rate } \\
(\%)\end{array}$ & $\begin{array}{l}\text { Mean } \\
\left(\text { g.d } d^{-1}\right)\end{array}$ & $\begin{array}{c}\text { Std } \\
\left(g^{-1} d^{-1}\right)\end{array}$ & $\begin{array}{c}\text { 95th perc. } \\
\text { (g. } \text { d-1) }^{-1}\end{array}$ & $\begin{array}{c}\text { Consumers rate } \\
(\%)\end{array}$ & $\begin{array}{l}\text { Mean } \\
\left(\mathrm{g} \cdot \mathrm{d}^{-1}\right)\end{array}$ \\
\hline Compotes and cooked fruits & 667 & 37.8 & 19.8 & 44.3 & 133.3 & 32.9 & 13.3 \\
\hline Seasonings and sauces & 1683 & 95.3 & 18.2 & 19.5 & 57.8 & 93.2 & 19.4 \\
\hline Food for particular uses & 880 & 49.8 & 18 & 87.7 & 100 & 12.3 & 2.8 \\
\hline
\end{tabular}


Table 3. Exposure to PCBs, dioxins and furans of the NutriNet-Santé study vegetarian populations and the general French population

\begin{tabular}{|c|c|c|c|c|c|c|c|c|}
\hline \multirow{3}{*}{ Population } & \multirow{3}{*}{ Contaminant } & \multirow{3}{*}{$n$} & \multicolumn{4}{|c|}{$\begin{array}{l}\text { NutriNet-Santé study } \\
\text {-Vegetarian population- }\end{array}$} & \multicolumn{2}{|c|}{$\begin{array}{c}\text { General population (Sirot et } \\
\text { al., 2010) }\end{array}$} \\
\hline & & & \multicolumn{2}{|c|}{ Mean } & \multicolumn{2}{|c|}{$95^{\text {th }}$ percentile } & \multirow{2}{*}{\begin{tabular}{|c|} 
Mean \\
MB \\
\end{tabular}} & \multirow{2}{*}{$\begin{array}{c}95^{\text {th }} \text { percentile } \\
\text { MB }\end{array}$} \\
\hline & & & LB & UB & LB & UB & & \\
\hline \multirow[t]{2}{*}{ Vegan } & $\begin{array}{c}\text { PCDD/Fs + dl-PCBs } \\
\text { (pg TEQwH02005.kg bw-1d- }\end{array}$ & 188 & 0.053 & 0.073 & 0.190 & $Y$ & & \\
\hline & $\begin{array}{c}\text { ndl-PCBs } \\
\left.\text { (ng.kg bw-1. } d^{-1}\right)\end{array}$ & 188 & 0.068 & 0.068 & 0.284 & 0.284 & & \\
\hline \multirow[t]{2}{*}{ Non Vegan } & $\begin{array}{c}\text { PCDD/Fs + dl-PCBs } \\
\text { (pg TEQwHo2005.kg bw-1d- }\end{array}$ & 1561 & 0.429 & 0.480 & 1.567 & 1.611 & & \\
\hline & $\begin{array}{c}\text { ndl-PCBs } \\
\left(n g \cdot k g ~ b w^{-1} \cdot d^{-1}\right)\end{array}$ & 1561 & 1.080 & 1.080 & 5.447 & 5.448 & & \\
\hline \multirow[t]{3}{*}{$\begin{array}{c}\text { All Vegetarian } \\
\text { habits }\end{array}$} & $\begin{array}{c}\text { PCDD/Fs + dl-PCBs } \\
\text { (pg TEQwHO2005.kg bw-1d- }\end{array}$ & 1749 & 0.39 & 0.44 & 1.46 & 1.56 & & \\
\hline & $\begin{array}{c}\text { ndl-PCBs } \\
\left.\text { (ng.kg bw-1. } \mathrm{d}^{-1}\right)\end{array}$ & 1749 & 0.97 & 0.97 & 4.64 & 4.64 & & \\
\hline & $\begin{array}{c}\text { PCDD/Fs + dl-PCBs } \\
\text { (pg TEQwH02005.kg bw-1-1- }\end{array}$ & 1918 & & & & & 0.4 & 0.83 \\
\hline
\end{tabular}




\begin{tabular}{|c|c|c|c|c|c|c|c|c|}
\hline & 1) & & & & & & & \\
\hline & $\begin{array}{c}\text { ndl-PCBs } \\
\left(\mathrm{ng}_{\mathrm{kg} \mathrm{bw}-1} \mathrm{~d}^{-1}\right)\end{array}$ & 1918 & & & & & 1.83 & 5.05 \\
\hline
\end{tabular}




\section{ACCEPTED MANUSCRIPT}

Table 4. Exposure to perfluoroalkyl acids of the NutriNet-Santé study vegetarian population (ng.kg bw $\left.{ }^{-1} \cdot d^{-1}\right)$

\begin{tabular}{|c|c|c|c|c|c|c|}
\cline { 2 - 7 } \multicolumn{1}{c|}{} & \multicolumn{3}{c|}{ Lower bound hypothesis } & \multicolumn{3}{c|}{ Upper bound hypothesis } \\
\cline { 2 - 7 } \multicolumn{1}{c|}{ Mean } & SD & $95^{\text {th }}$ percentile & Mean & SD & $95^{\text {th }}$ percentile \\
\hline PFOS & 0.03 & 0.12 & 0.18 & 0.45 & 0.30 & 1.02 \\
\hline PFOA & 0.01 & 0.01 & 0.02 & 0.43 & 0.28 & 0.96 \\
\hline
\end{tabular}




\section{ACCEPTED MANUSCRIPT}

Table 5. Exposure to brominated flame retardants of the NutriNet-Santé study vegetarian population (ng.kg bw $\left.{ }^{-1} \cdot d^{-1}\right)$

\begin{tabular}{|l|c|c|c|c|c|c|}
\cline { 2 - 7 } \multicolumn{1}{c|}{} & \multicolumn{3}{c|}{ Lower bound hypothesis } & \multicolumn{3}{c|}{ Upper bound hypothesis } \\
\cline { 2 - 7 } \multicolumn{1}{c|}{} & Mean & SD & 95 $5^{\text {th }}$ percentile & Mean & SD & $9^{\text {th }}$ percentile \\
\hline HBCDD & 0.04 & 0.09 & 0.19 & 0.05 & 0.97 & 0.21 \\
\hline PBB & 0.00 & 0.00 & 0.01 & 0.01 & 0.01 & 0.02 \\
\hline 7-PBDE & 0.11 & 0.29 & 0.57 & 0.12 & 0.29 & 0.57 \\
\hline 7-PBDE + PBDE209 & 0.25 & 0.37 & 0.90 & 0.27 & 0.38 & 0.93 \\
\hline
\end{tabular}




\section{ACCEPTED MANUSCRIPT}

Table 6. Exposure to trace elements and minerals of the NutriNet-Santé study vegetarian population

\begin{tabular}{|c|c|c|c|c|c|c|}
\hline & \multicolumn{3}{|c|}{ Lower bound hypothesis } & \multicolumn{3}{|c|}{ Upper bound hypothesis } \\
\hline & Mean & SD & 95th percentile & Mean & SD & 95th percentile. \\
\hline $\begin{array}{l}\text { As } \\
\left(\mu g \cdot \mathrm{kg} \mathrm{bw}^{-1} \cdot \mathrm{d}^{-1}\right)\end{array}$ & 0.56 & 0.81 & 2.08 & 0.82 & 0.64 & 2.17 \\
\hline $\begin{array}{l}\mathrm{Pb} \\
\left(\mu \mathrm{g} \cdot \mathrm{kg} \mathrm{bw}^{-1} \cdot \mathrm{d}^{-1}\right)\end{array}$ & 0.18 & 0.08 & 0.33 & 0.09 & 0.23 & 0.4 \\
\hline $\begin{array}{l}\mathrm{Cd} \\
\left(\mu \mathrm{g} \cdot \mathrm{kg} \mathrm{bw}^{-1} \cdot \mathrm{d}^{-1}\right)\end{array}$ & 1.12 & 0.06 & 1.96 & 0.07 & 1.19 & 2.03 \\
\hline $\begin{array}{l}\text { Al } \\
\left(m g \cdot k g ~ b w^{-1} \cdot d^{-1}\right)\end{array}$ & 0.39 & 0.03 & 0.74 & 0.03 & 0.4 & 0.76 \\
\hline $\begin{array}{l}\mathrm{Hg} \\
\left(\mu g \cdot \mathrm{kg} \mathrm{bw}^{-1} \cdot \mathrm{d}^{-1}\right)\end{array}$ & 0.02 & 0.03 & 0.07 & 0.07 & 0.16 & 0.28 \\
\hline $\begin{array}{l}\text { Sn } \\
\left(\mu g \cdot \mathrm{kg} \mathrm{bw}^{-1} \cdot \mathrm{d}^{-1}\right)\end{array}$ & 6.3 & 20.67 & 31.07 & 20.68 & 6.32 & 31.08 \\
\hline $\begin{array}{l}\mathrm{Ni} \\
\left(\mu \mathrm{g} \cdot \mathrm{kg} \mathrm{bw}^{-1} \cdot \mathrm{d}^{-1}\right)\end{array}$ & 2.95 & 1.34 & 5.45 & 1.44 & 3.36 & 6.16 \\
\hline $\begin{array}{l}\mathrm{Ca} \\
\left(\mathrm{mg} \cdot \mathrm{d}^{-1}\right)\end{array}$ & 579.7 & & 1054.7 & 0 & 580.5 & 1055.4 \\
\hline $\begin{array}{l}\mathrm{Mg} \\
\left(\mathrm{mg} \cdot \mathrm{d}^{-1}\right)\end{array}$ & 284.4 & 0 & 453 & 0 & 284.5 & 453.1 \\
\hline $\begin{array}{l}\mathrm{Cu} \\
\left(\mathrm{mg} \cdot \mathrm{d}^{-1}\right)\end{array}$ & 1.59 & 0.01 & 2.98 & 0.01 & 1.59 & 2.98 \\
\hline $\begin{array}{l}\mathrm{Na} \\
\left(\mathrm{g} \cdot \mathrm{d}^{-1}\right)\end{array}$ & 1.65 & 0.01 & 2.85 & 0.01 & 1.66 & 2.86 \\
\hline $\begin{array}{l}\mathrm{Fe} \\
\left(\mathrm{mg} \cdot \mathrm{d}^{-1}\right)\end{array}$ & 7.13 & 0.06 & 13.06 & 0.06 & 7.14 & 13.06 \\
\hline
\end{tabular}


Table 7. Exposure to mycotoxins of the NutriNet-Santé study vegetarian population (ng.kg bw $\left.{ }^{1} \cdot d^{-1}\right)$

\begin{tabular}{|l|c|c|c|c|c|c|}
\cline { 2 - 7 } \multicolumn{1}{c|}{} & \multicolumn{3}{c|}{ Lower bound hypothesis } & \multicolumn{3}{c|}{ Upper bound hypothesis } \\
\cline { 2 - 8 } \multicolumn{1}{c|}{} & Mean & SD & $95^{\text {th }}$ percentile & Mean & SD & $95^{\text {th }}$ percentile \\
\hline Aflatoxins & 0 & 0 & 0 & 0.38 & 0.78 & 1.49 \\
\hline Fumonisin B1 & 8.89 & 16.03 & 31.39 & 24.17 & 25.74 & 63.85 \\
\hline Fumonisin B2 & 2.39 & 7.82 & 12.5 & 11.71 & 12.66 & 32.55 \\
\hline & & & & & & \\
\hline T2 and HT-2 toxins & 9.33 & 6.46 & 21.54 & 26.73 & 50.37 & 99.56 \\
\hline Deoxynivalenol & 285 & 179.2 & 60.9 & 192.7 & 320.9 & 670.4 \\
\hline Nivalenol & 16.8 & 17.9 & 51.3 & 21.1 & 31.2 & 70.6 \\
\hline Zearalenone & 5.7 & 3 & 11.2 & 10.5 & 26 & 45.3 \\
\hline Ochratoxin A & 0.21 & 0.17 & 0.54 & 0.86 & 1.91 & 3.48 \\
\hline Patulin & 1.03 & 1.6 & 4.17 & 24.71 & 29.19 & 71.7 \\
\hline
\end{tabular}

Table 8. Exposure to phytoestrogens of the NutriNet-Santé study vegetarian population

\begin{tabular}{|c|c|c|c|c|c|c|}
\hline & \multicolumn{3}{|c|}{ Lower bound hypothesis } & \multicolumn{3}{|c|}{ Upper bound hypothesis } \\
\hline & Mean & SD & $95^{\text {th }}$ percentile & Mean & SD & $95^{\text {th }}$ percentile \\
\hline $\begin{array}{l}\text { Isoflavones } \\
\left(\mu \mathrm{g} \cdot \mathrm{kg} \mathrm{bw}^{-1} \cdot \mathrm{d}^{-1}\right)\end{array}$ & 199.1 & 306.4 & 794.1 & 306.6 & 199.7 & 795 \\
\hline $\begin{array}{l}\text { Lignans } \\
\left(\mu \mathrm{g} \cdot \mathrm{kg} \mathrm{bw}^{-1} \cdot \mathrm{d}^{-1}\right)\end{array}$ & 2.64 & 3.79 & 9.38 & 3.71 & 3.24 & 10.1 \\
\hline $\begin{array}{l}\text { Coumestrans } \\
\left(\mathrm{ng} \cdot \mathrm{kg} \mathrm{bw}^{-1} \cdot \mathrm{d}^{-1}\right)\end{array}$ & 123 & 398.3 & 775.2 & 559.5 & 594.5 & 1630.5 \\
\hline
\end{tabular}

Isoflavones comprise genistein, biochanin A, daidzein, formononetion and glycitein

Lignans comprise matairesinol and secoisolariciresinol 


\section{ACCEPTED MANUSCRIPT}

Table 9. Exposure of the NutriNet-Santé study vegetarian population to acrylamide and polycyclic aromatic hydrocarbons

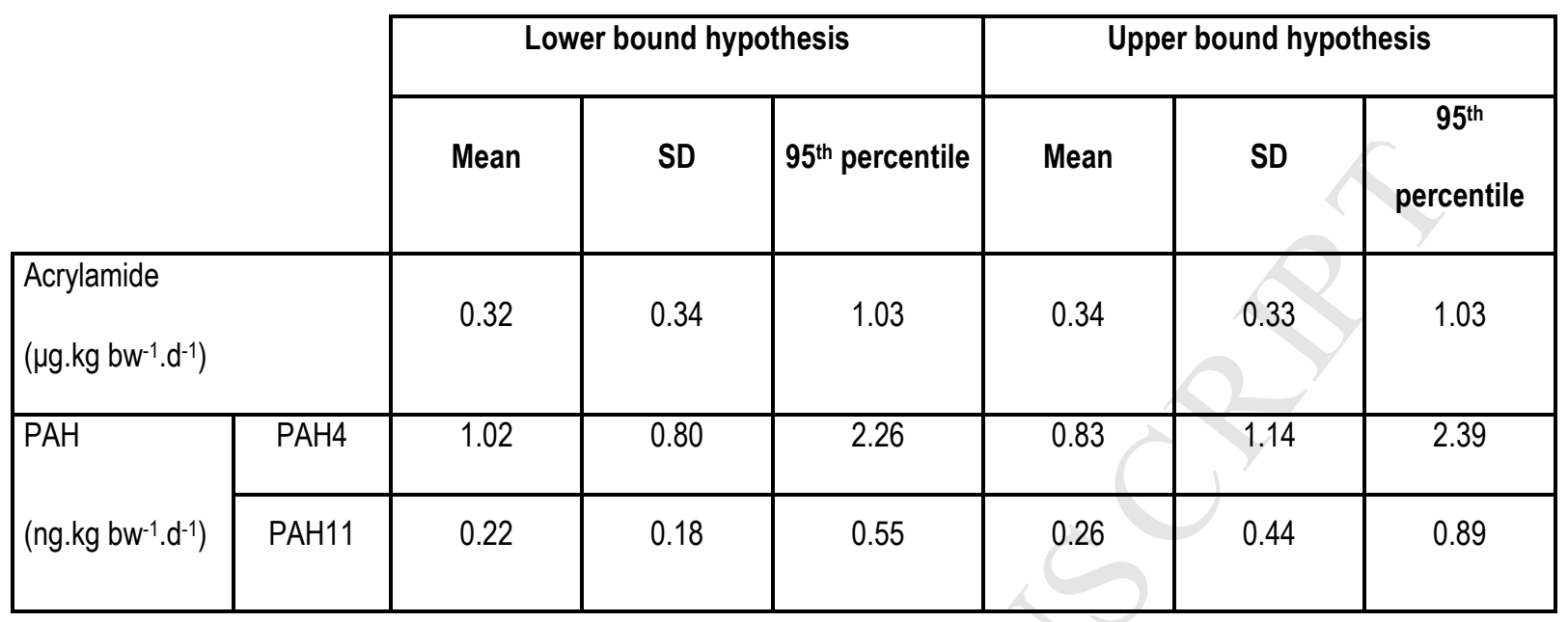




\section{ACCEPTED MANUSCRIPT}

Table 10. Margin of exposures (MOE) for inorganic arsenic in the NutriNet-Santé study vegetarian population and the general French population

\begin{tabular}{|c|c|c|c|c|c|c|}
\hline \multirow{3}{*}{$\begin{array}{c}\text { BMDL }_{01} \\
\left(\mu \mathrm{g} \cdot \mathrm{kg} \mathrm{bw}^{-1} . \mathrm{d}^{-1}\right)\end{array}$} & \multicolumn{4}{|c|}{$\begin{array}{l}\text { NutriNet-Santé study } \\
\text {-Vegetarian population- }\end{array}$} & \multicolumn{2}{|c|}{$\begin{array}{c}\text {-General population-(Arnich et } \\
\text { al. 2010) }\end{array}$} \\
\hline & \multicolumn{2}{|c|}{ Mean } & \multicolumn{2}{|c|}{$95^{\text {th }}$ percentile } & Mean & $95^{\text {th }}$ percentile \\
\hline & LB & UB & LB & UB & MB & MB \\
\hline 0.3 & 0.53 & 0.47 & 0.14 & 0.14 & 1.1 & 0.6 \\
\hline 8 & 14 & 12 & 3.85 & 3.69 & 29 & 16 \\
\hline
\end{tabular}




\section{ACCEPTED MANUSCRIPT}

Table 11. Lead exposure margin (MOE) for the NutriNet-Santé study vegetarian population and the general French population

\begin{tabular}{|c|c|c|c|c|c|c|c|}
\hline \multirow{3}{*}{$\begin{array}{c}\mathrm{BMDL}_{10} \\
\left(\mu \mathrm{gg} \cdot \mathrm{kg} \mathrm{bw}^{-1} \cdot \mathrm{d}^{-1}\right)\end{array}$} & \multirow{3}{*}{ Target organs } & \multicolumn{4}{|c|}{$\begin{array}{l}\text { NutriNet-Santé study } \\
\text { Vegetarian population }\end{array}$} & \multicolumn{2}{|c|}{$\begin{array}{l}\text { General population } \\
\text { (Arnich et al., 2010) }\end{array}$} \\
\hline & & \multicolumn{2}{|c|}{ Mean } & \multicolumn{2}{|c|}{$95^{\text {th }}$ percentile } & Mean & $95^{\text {th }}$ percentile \\
\hline & & LB & UB & LB & UB & MB & MB \\
\hline 1.5 & cardiovascular & 8.3 & 6.5 & 4.5 & 3.8 & 7.5 & 4.3 \\
\hline 0.63 & nephrotoxic & 3.5 & 2.7 & 1.9 & 1.6 & 3.2 & 1.8 \\
\hline
\end{tabular}




\section{ACCEPTED MANUSCRIPT}

Table 12. Summary of the exposure to acrylamide results of vegetarian from NutriNet-Santé study population and general French population from TDS2, and the margin of exposure (MoE)

\begin{tabular}{|c|c|c|c|c|c|}
\hline \multirow{2}{*}{$\begin{array}{c}\text { BMDL10 } \\
\left(\mu g \mathrm{~kg} \mathrm{bw}^{-1} \cdot \mathrm{d}^{-1}\right)\end{array}$} & & \multicolumn{2}{|c|}{$\begin{array}{l}\text { NutriNet-Santé study } \\
\text {-Vegetarian population- }\end{array}$} & \multicolumn{2}{|c|}{-General population- } \\
\hline & & Mean & $\begin{array}{c}95^{\text {th }} \\
\text { percentile }\end{array}$ & Mean & $\begin{array}{c}\text { 95 th } \\
\text { percentile }\end{array}$ \\
\hline \multirow[t]{2}{*}{310} & $\begin{array}{c}\text { Exposure } \\
\left(\mu g \cdot \mathrm{kg} \mathrm{bw}^{-1} \cdot \mathrm{d}^{-1}\right)\end{array}$ & 0,32 & 1,03 & 0,43 & 1,02 \\
\hline & MOE & 955 & 302 & 721 & 304 \\
\hline \multirow[t]{2}{*}{180} & $\begin{array}{c}\text { Exposure } \\
\left(\mu g \cdot \mathrm{kg} \mathrm{bw}^{-1} \cdot \mathrm{d}^{-1}\right)\end{array}$ & 0,32 & 1,03 & 0,43 & 1,02 \\
\hline & MOE & 554 & 175 & 419 & 176 \\
\hline
\end{tabular}




\section{ACCEPTED MANUSCRIPT}

Table 13. PAH margin of exposure concerning vegetarian from the NutriNet-Santé study population and the general French population

\begin{tabular}{|c|c|c|c|c|c|c|c|}
\hline & \multirow{3}{*}{$\begin{array}{l}\text { Health-Based } \\
\text { Guidance Values } \\
\left(\mathrm{mg} \mathrm{kg} \mathrm{bw}^{-1} \cdot \mathrm{d}^{-1}\right)\end{array}$} & \multicolumn{4}{|c|}{$\begin{array}{l}\text { NutriNet-Santé study } \\
\text {-Vegetarian population- }\end{array}$} & \multicolumn{2}{|c|}{$\begin{array}{l}\text { General population } \\
\text { (Veyrand et al. 2013) }\end{array}$} \\
\hline & & \multicolumn{2}{|c|}{ Mean } & \multicolumn{2}{|c|}{$95^{\text {th }}$ percentile } & \multirow{2}{*}{$\begin{array}{c}\text { Mean } \\
\text { MB }\end{array}$} & \multirow{2}{*}{$\begin{array}{c}9^{\text {th }} \\
\text { percentile } \\
\text { MB }\end{array}$} \\
\hline & & LB & UB & LB & UB & & \\
\hline $\mathrm{PAH4}$ & $\mathrm{BMDL}_{10}=340000$ & 335000 & 298000 & 150000 & 142000 & 230000 & 72400 \\
\hline PAH11 & SVD $=5$ & 20 & 16 & 8 & 7 & 14 & 12 \\
\hline
\end{tabular}




\section{Exposure to contaminants and nutritional intakes in a French vegetarian population}

S. Fleury ${ }^{1, a}$, G. Rivière ${ }^{1, a}$, B. Allès ${ }^{2}$, E. Kesse-Guyot ${ }^{2}$, C. Méjean ${ }^{2}$, S. Hercberg ${ }^{2}$, M. Touvier $^{2}$ and N. Bemrah $^{1 *}$

${ }^{1}$ Risk Assessment Unit - French Agency for Food, Environmental and Occupational Health \& Safety (ANSES), Maisons-Alfort, France.

${ }^{2}$ Sorbonne Paris Cité Epidemiology and Statistics Research Center (CRESS), Nutritional Epidemiology Research Team (EREN), Inserm U1153, Inra U1125, Conservatoire National des Arts et Métiers (CNAM), Paris 5, 7, 13 Universities,F-93017 Bobigny, France

The conclusions presented in the present article represent authors' views only.

${ }^{a}$ These authors contributed equally to this work.

\section{Highlights}

- Dietary exposures of French vegetarian populations to several contaminants were estimated.

- Exposures to persistent organic pollutants (PCBs, PCDD/Fs for instance) was dramatically lower than those of the general French population due to the non consumption of food of animal origins.

- Exposures to phytoestrogens, some mycotoxins (T2 and HT2 toxins) and some trace elements $(\mathrm{Cd}, \mathrm{Al}, \mathrm{Sn}, \mathrm{Ni})$ were higher in the vegetarian population compared to those of the general population.

\footnotetext{
"Corresponding author : Nawel Bemrah
}

Agence Nationale de Sécurité Sanitaire de l'alimentation, de l'environnement et du travail (Anses)

DER/UERALIM

ACl-COP-4-031

14 rue Pierre et Marie Curie - 94701 Maisons-Alfort Cedex

Tel: +33149773829

Email: nawel.bemrah@anses.fr 